\title{
COVID-19 pandemic crisis-a complete outline of SARS-CoV-2
}

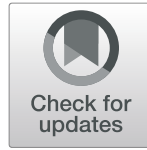

\author{
Sana Saffiruddin Shaikh ${ }^{{ }^{*}} \mathbb{D}$, Anooja P. Jose ${ }^{2}$, Disha Anil Nerkar², Midhuna Vijaykumar KV² and \\ Saquib Khaleel Shaikh ${ }^{1}$
}

\begin{abstract}
Background: Coronavirus (SARS-CoV-2), the cause of COVID-19, a fatal disease emerged from Wuhan, a large city in the Chinese province of Hubei in December 2019.

Main body of abstract: The World Health Organization declared COVID-19 as a pandemic due to its spread to other countries inside and outside Asia. Initial confirmation of the pandemic shows patient exposure to the Huanan seafood market. Bats might be a significant host for the spread of coronaviruses via an unknown intermediate host. The human-to-human transfer has become a significant concern due to one of the significant reasons that is asymptomatic carriers or silent spreaders. No data is obtained regarding prophylactic treatment for COVID-19, although many clinical trials are underway.

Conclusion: The most effective weapon is prevention and precaution to avoid the spread of the pandemic. In this current review, we outline pathogenesis, diagnosis, treatment, ongoing clinical trials, prevention, and precautions. We have also highlighted the impact of pandemic worldwide and challenges that can help to overcome the fatal disease in the future.
\end{abstract}

Keywords: COVID-19, SARS-CoV-2, Lifecycle, Pathogenesis, Prevention, Clinical trials

\section{Background}

Coronaviruses (CoVs) are a large family of RNA viruses; they show discrete point-like projections over their surface. They show the presence of an unusually large RNA genome and a distinctive replication strategy. The term "coronavirus" is acquired from the "crown"-like morphology. Coronaviruses show potential fatal human respiratory infections and cause a variety of diseases in animals and birds [1]. Coronavirus primarily targets the human respiratory system [2]. The World Health Organization (WHO) named the latest virus as severe acute respiratory syndrome coronavirus 2 (SARS-CoV-2) on 12 January 2020 [3]. The COVID-19 or the SARS-CoV-2 is rapidly unfurling from Wuhan in Hubei Province of China to worldwide [4].

\footnotetext{
* Correspondence: sana.shaikh310194@gmail.com

${ }^{1} Y$. B. Chavan College of Pharmacy, Dr. Rafiq Zakaria Campus, Aurangabad 431001, India

Full list of author information is available at the end of the article
}

Initial confirmation of the pandemic was carried out by conducting studies on 99 patients with COVID-19 pneumonia, from which $49 \%$ of patients exhibited a history of subjection to the Huanan seafood market. The patient examined had a clinical manifestation of fever, cough, shortness of breath, muscle ache, and sore throat-like symptoms [5]. COVID-19 has infected several hundreds of humans and has caused many fatal cases [6]. Worldwide, there have been 3,925,815 confirmed cases, including 274,488 deaths of COVID-19 as of 6:37 pm CEST 10 May 2020 reported to WHO [7].

This article outlines and gives a complete overview of SARS-CoV-2, including its pathogenesis, diagnosis, treatment, prevention, and precautions. This article also provides the current scenario of the pandemic worldwide, since new findings are rapidly evolving and can help the readers in upgrading their knowledge about the COVID-19. It also emphasizes the challenges faced by giving an idea about future strategies in fighting and preventing recurrence.

\section{Springer Open}

(ㅇ The Author(s). 2020 Open Access This article is licensed under a Creative Commons Attribution 4.0 International License, which permits use, sharing, adaptation, distribution and reproduction in any medium or format, as long as you give appropriate credit to the original author(s) and the source, provide a link to the Creative Commons licence, and indicate if changes were made. The images or other third party material in this article are included in the article's Creative Commons licence, unless indicated otherwise in a credit line to the material. If material is not included in the article's Creative Commons licence and your intended use is not permitted by statutory regulation or exceeds the permitted use, you will need to obtain permission directly from the copyright holder. To view a copy of this licence, visit http://creativecommons.org/licenses/by/4.0/. 


\section{Main text}

\section{History and origin}

Coronaviruses were not expected to be highly infectious to humans, but the outburst of a severe acute respiratory syndrome (SARS) in Guangdong province China in the years 2002 and 2003 proved to be devastating. SARS-CoV is the contributory agent of the SARS, also known as "atypical pneumonia". The coronaviruses that spread before that time in humans mostly caused mild infections in immunecompetent people. But after the emergence of SARS, another highly infectious coronavirus, MERS-CoV, appeared in Middle Eastern countries [8,9]. Research has shown that SARS-CoV-2 shows similarities with SARS-CoV and MERS-CoV. (Table 1) depicts a comparison of SARS-CoV2 with SARS-CoV and MERS-CoV [10-16]. Several disseminating strains of coronaviruses were identified and were considered harmless pathogens, causing common cold and mild upper respiratory illness [17]. HCoV-229E [18] strain was isolated in 1966. HCoV-NL63 was first isolated from the Netherlands during late 2004. In 2012, MERS-CoV was first identified from the lung of a 60-year-old patient who was suffering from acute pneumonia and renal failure in Saudi Arabia [19]. About 8000 cases and 800 deaths worldwide were observed due to the outbreak of SARS first human pandemic in the dawn of the twenty-first century [20].

The $\alpha$-CoVs HCoV-229E and HCoV-NL63 and $\beta$ CoVs HCoV-HKU1 and HCoV-OC43 are identified as a human susceptible virus with low pathogenicity and cause mild respiratory symptoms similar to common cold [21]. SARS-CoV and MERS-CoV result in severe respiratory tract infections $[22,23]$. COVID-19 was

Table 1 Comparison of coronaviruses

\begin{tabular}{|c|c|c|c|}
\hline Parameters & SARS-COV2 & SARS-COV & MERS-COV \\
\hline Epidemiology & Dec 2019, Wuhan, China & Nov 2002, Guangdong, China & April 2012, Saudi Arabia \\
\hline Animal reservoir & Bats & Bats & Bats \\
\hline Intermediate host & $\begin{array}{l}\text { Pangolins/minks } \\
\text { (yet to be confirmed) }\end{array}$ & Palm civets & Camels \\
\hline Receptor target & ACE2 & ACE2 & DPP4 \\
\hline Fatality rate & $2.3 \%$ & $9.5 \%$ & $34.4 \%$ \\
\hline $\begin{array}{l}\text { Genetic similarity with the } \\
\text { other }\end{array}$ & $\begin{array}{l}79.5 \% \text { SARS-COV } \\
50 \% \text { MERS-CoV }\end{array}$ & $79.5 \%$ SARS-CoV-2 & $50 \%$ SARS-CoV-2 \\
\hline Virus type & SS-RNA & RNA & RNA \\
\hline $\begin{array}{l}\text { Total RNA sequence } \\
\text { length of pathogen }\end{array}$ & $29,903 \mathrm{bp}$ & $29,751 \mathrm{bp}$ & $30,108 \mathrm{bp}$ \\
\hline M:F ratio & $2.70: 1$ & $1: 1.25$ & $2: 1$ \\
\hline Transmission route & $\begin{array}{l}\text { Droplets; faeco-oral } \\
\text { transmission; contact with } \\
\text { infected individual or things } \\
\text { Human-to-human }\end{array}$ & $\begin{array}{l}\text { Droplets; contact with infected } \\
\text { individual or things; } \\
\text { bat-civets-human } \\
\text { Human-to-human }\end{array}$ & $\begin{array}{l}\text { Touching infected camel or consumption of meat or } \\
\text { milk } \\
\text { Limited human-to-human transmission }\end{array}$ \\
\hline Clinical symptoms & Fever, fatigue, dry cough & $\begin{array}{l}\text { Fever, cough, myalgia, dyspnea, } \\
\text { diarrhea }\end{array}$ & Fever, cough, respiratory distress, vomiting, diarrhea \\
\hline Incubation & 7-14 days, 24 days & $2-7$ days & $5-6$ days \\
\hline $\mathrm{R}_{0}$ & 2.68 & 2.5 & $>1$ \\
\hline Diagnostic methods & $\begin{array}{l}\text { RRT-PCR, RT-PCR, RT-lamp, } \\
\text { RRT-lamp, coronavirus } \\
\text { detection kit }\end{array}$ & $\begin{array}{l}\text { RRT-PCR, RT-PCR, RT-lamp, RRT- } \\
\text { lamp, coronavirus detection kit }\end{array}$ & $\begin{array}{l}\text { RRT-PCR, ELISA, micro neutralization assay, MERS-CoV } \\
\text { serology test }\end{array}$ \\
\hline Chest X-ray & $\begin{array}{l}\text { Bilateral multi-lobular ground } \\
\text { glass opacities }\end{array}$ & Ground glass opacities & Ground glass opacities; consolidation \\
\hline Chest CT scan & No nodular opacities & $\begin{array}{l}\text { Lobar consolidation; nodular } \\
\text { opacities }\end{array}$ & $\begin{array}{l}\text { Single or multiple opacities; bilateral glass opacities; } \\
\text { sub-pleural and lower lobe predominance; septal } \\
\text { thickness }\end{array}$ \\
\hline Prevention & $\begin{array}{l}\text { Hand hygiene; cough etiquette; } \\
\text { avoiding unnecessary touching } \\
\text { of the eyes or face. }\end{array}$ & $\begin{array}{l}\text { Hand hygiene; cough etiquette; } \\
\text { avoiding unnecessary touching } \\
\text { of the eyes or face. }\end{array}$ & $\begin{array}{l}\text { Hand hygiene; cough etiquette; avoiding unnecessary } \\
\text { touching of the eyes or face; avoiding raw milk and } \\
\text { meat consumption. }\end{array}$ \\
\hline Treatment & Ritonavir; lopinavir (in testing) & Glucocorticoids; interferon & $\begin{array}{l}\text { Ribavirin; interferon; analgesics (treatment not yet } \\
\text { determined) }\end{array}$ \\
\hline
\end{tabular}


recently reported from Wuhan (China), which has cases in Thailand, Japan, South Korea, and the USA, which has been confirmed as a new coronavirus [24].

The coronavirus genera, which mostly infect mammals, are alpha-coronavirus and beta-coronavirus. Out of 15 presently assigned viral species, seven were isolated from bats. The research proposed that bats are significant hosts for alpha-coronaviruses and beta-coronaviruses and play an essential role as the gene source in the evolution of these two coronavirus genera SARS and MERS [25]. The genome sequence was found to be $96.2 \%$ identical to a bat CoV RaTG13, whereas it shares $79.5 \%$ identity to SARS$\mathrm{CoV}$. The virus genome sequencing outcomes and evolutionary analysis show that bat can be a natural host from virus source, and SARS-CoV-2 might be transferred from bats through unspecified intermediate hosts to infect humans [26]. It is found that SARS-CoV-2 affects males more than females [27]. The spread of SARS-CoV-2 emerged like a wild forest fire in many countries worldwide. Table (2) [28] gives a brief of the first identified cases of COVID-19 in different countries.

\section{Structure}

Coronaviruses are spherical to pleomorphic enveloped particles [29]. The size ranges from 80 to $120 \mathrm{~nm}$ in diameter. The maximum size is as small as $50 \mathrm{~nm}$ and as large as $200 \mathrm{~nm}$ are also seen [30]. There are four types

Table 2 First confirmed case

\begin{tabular}{ll}
\hline Country & First confirmed case (dates) \\
\hline China, East Asia & 31 December 2019 \\
Thailand & 13 January 2020 \\
Japan & 15 January 2020 \\
Korea & 20 January 2020 \\
USA & 23 January 2020 \\
Vietnam & 24 January 2020 \\
Singapore & 24 January 2020 \\
Australia, Nepal, and French Republic & 25 January 2020 \\
Malaysia & 26 January 2020 \\
Canada & 27 January 2020 \\
Cambodia, Germany, Sri Lanka & 28 January 2020 \\
United Arab Emirates & 29 January 2020 \\
Philippines, India, Finland & 30 January 2020 \\
Italy & 31 January 2020 \\
Russian Federation, Spain, Sweden, UK & 1 February 2020 \\
Belgium & 5 February 2020 \\
Japan & 6 February 2020 \\
Egypt & 15 February 2020 \\
\hline
\end{tabular}

The first confirmed case was reported in China, and since then, there was a widespread of coronavirus in other countries worldwide. Table 1 shows the first confirmed case with dates of main structural proteins observed in the coronaviruses: the spike $(S)$, membrane $(M)$, envelope $(E)$, and nucleocapsid $(\mathrm{N})$ proteins, which are encoded within the viral genome (Table 3). In thin sections, the virion envelope may be visualized as inner and outer shells separated by a translucent space [31]. The virion envelope contains phospholipids, glycolipids, cholesterol, di- and triglycerides, and free fatty acids in proportions. The complexed genome RNA is with the basic nucleocapsid (N) protein, which forms a helical capsid established within the viral membrane. The enclosed glycoproteins are responsible for attachment to the host cells [32].

The coronavirus genomes are among the most massive mature RNA molecules as compared to other eukaryotic RNAs (Fig. 1) [33]. The genome of these viruses contains multiple ORFS. A typical $\mathrm{CoV}$ consists of at least 6 ORFs in its genome. Several studies have confirmed the genetic resemblance between SARS-CoV-2 and a bat CoV.

A study conducted to compare the genetic mutations of COVID showed genomic mutations among viruses from different countries, wherein a sequence obtained from Nepal showed minimum to no variations. In contrast, the maximum number of modifications was obtained from one derived from the Indian series located in ORF1-ab nsp2 nsp3 helicase ORF8 and spike surface glycoprotein. Also, host antiviral mRNAs play a critical part in the regulation of immune response to virus infection, depending upon the viral agent. The unique host mRNAs could be explored in the development of novel antiviral therapies. The club-like surface projections or peplomers of coronaviruses are about $17-20 \mathrm{~nm}$ from the virion surface. It has a subtle base that swells to a width of about $10 \mathrm{~nm}$ at the distal extremity. Some coronaviruses that exhibit the second set of projections about 5-10-nm long are present beneath the significant projections. These shorter spikes are now known as hemagglutinin-esterase (HE) protein, an additional membrane protein found in a subset of group 2 coronaviruses. The primary role of this non-essential protein is to aid in viral entry and pathogenesis in vivo. It configures short projections that bind to $\mathrm{N}$ acetyl-9-O-acetlyneuramic acid or $\mathrm{N}$-glycolylneuraminic acid and have esterase [34-39]. Figure 2 shows the primary classification of coronavirus.

\section{Lifecycle of coronavirus}

The life cycle of the virus with the host consists of the following four steps: attachment, penetration, biosynthesis, maturation, and release (Fig. 3). Once the virus binds to the host receptor, they enter host cells through endocytosis or membrane fusion. Once the viral contents are released inside the host cells, viral RNA enters the nucleus for replication. Viral mRNA is used to make 
Table 3 Structural proteins of coronavirus and their functions

\begin{tabular}{ll}
\hline Structural proteins & Functions of proteins \\
\hline Spike protein $(\mathrm{S})$ & Virus and host cell fusion by binding \\
Membrane protein $(\mathrm{M})$ & Nutrient transport, determines shape, and formation of envelope \\
Envelope protein $(\mathrm{E})$ & Interferes with host immune response \\
Nucleocapsid protein $(\mathrm{N})$ & Binds with RNA genome and makes up nucleocapsid \\
Hemagglutinin-esterase $(\mathrm{HE})$ & Binds sialic acids on surface glycoprotein \\
\hline
\end{tabular}

According to the recent studies, it is observed that coronavirus which lacks envelope protein (E) serves as a good candidate in vaccine designing

viral proteins and is further proceeded by maturation and release $[40,41]$.

\section{Attachment and entry}

The virion attachment with the host cell is initiated by interaction between $\mathrm{S}$ protein and its receptors, which is also a primary determinant for coronavirus infection. The $S$ protein undergoes acid-dependent proteolytic cleavage, which results in exposure of fusion peptide. This fusion is followed by the formation of a six-helix bundle (bundle formation helps in combining viral and cellular membrane) and release of the viral genome into the cytoplasm.

\section{Replicase protein expression}

The process of translation of replicase gene ORFs1a and ORFs1b and translation of polyprotein ppla and pplab takes place. Assembly of nsps into replicase-transcriptase complex (RTC) leads to viral RNA synthesis (replication and transcription of subgenomic RNAs).

\section{Replication and transcription}

In the replication process, the viral RNA synthesis is followed by the production of genomic and sub-genomic
RNAs (sub-genomic mRNAs), which further leads to recombination of the virus.

\section{Assembly and release}

The insertion and translation of viral structure protein $\mathrm{S}, \mathrm{E}$, and $\mathrm{M}$ takes place into the endoplasmic reticulum (ER), which is followed by the movement of proteins along the secretory pathway into ERGIC (endoplasmic reticulum Golgi intermediate compartment). The viral genome is encapsidated by $\mathrm{N}$ protein into the membrane of ERGIC. $\mathrm{M}$ and $\mathrm{E}$ protein expression give rise to the formation of virus-like particles (VLPs). After the assembly of the virion and its transportation to cell surface vesicles, exocytosis takes place. Finally, it results in viral release (E protein helps by altering the host secretory pathway).

\section{Incubation}

The incubation period is the period between the entry of the virus into the host and appearance of signs and symptoms in the host or the period between the earliest date of contact of the transmission source and the most initial time of symptom onset (i.e., cough, fever, fatigue,

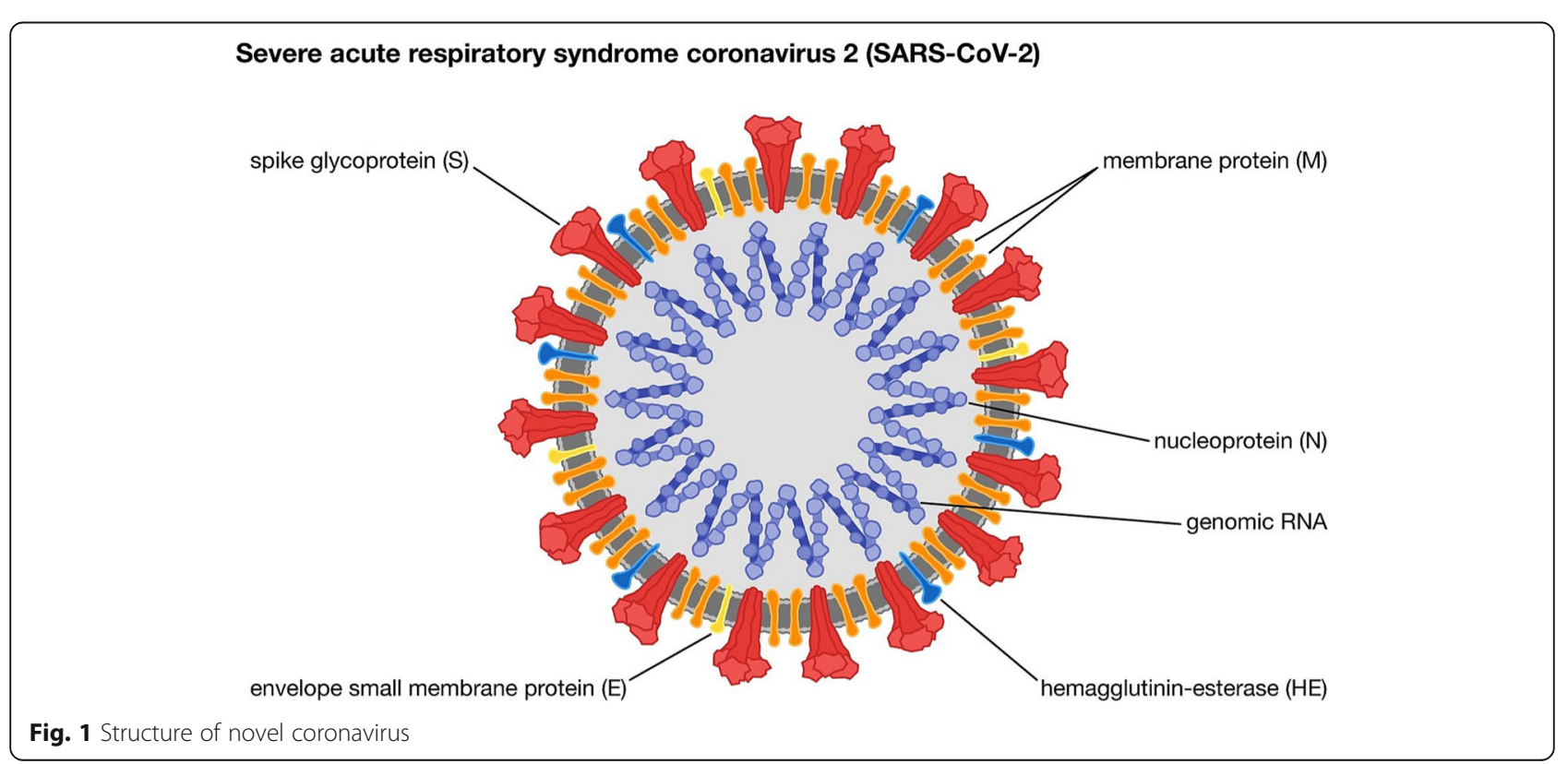




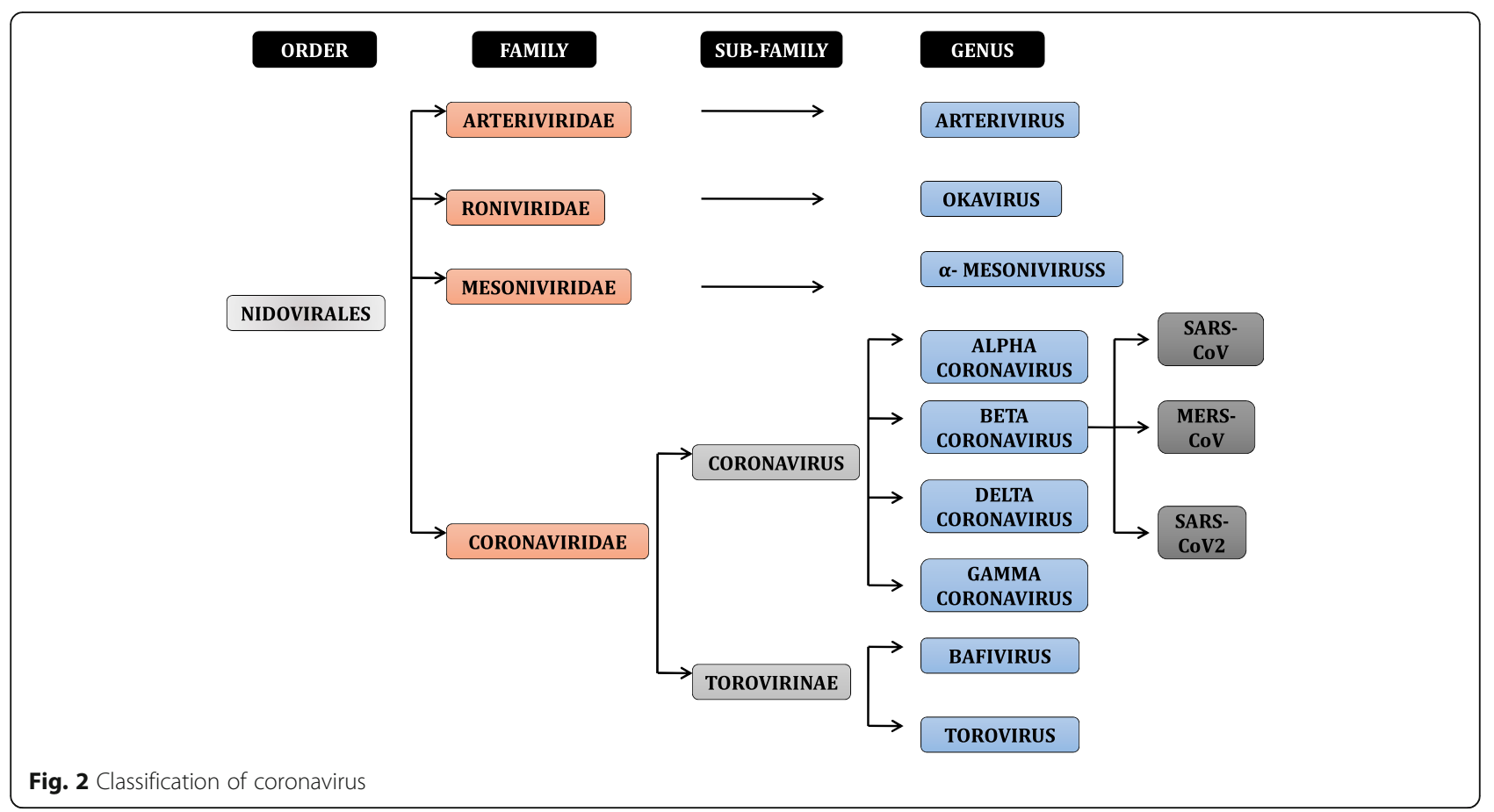

or myalgia) [42]. The incubation period of COVID-19 is vital as the disease could be transmitted during this phase through asymptomatic as well as symptomatic carriers (Table 4). The inhaled virus SARS-CoV-2 binds to the epithelial cells present in the nasal cavity and starts replicating.

ACE2 is the primary receptor for both SARS-CoV-2 and SARS-CoV, which is an asymptomatic state (initial 1-2 days of infection). Upper airway and conducting airway response are seen the next few days. The disease is mild and mostly restricted only to the upper conducting airways for about $80 \%$ of the infected patients [43].

The incubation period is required to create more productive quarantine systems for people infected with the virus. The incubation period for the COVID-19 is between 2 and 14 days after exposure. A newly infected person shows symptoms in the about 5 days after contact with a sick patient. In most patients, symptoms appeared after 12-14 days of infection

The average incubation period was approximated to be 5.1 days, and $97.5 \%$ of those who develop symptoms will do so within 11.5 days of infection. In Wuhan's return patients, the average incubation period is found to be 6.4 days. In a case reported by Hubei province, local government on 22 February showed an incubation period of 27 days. In another case, an incubation period of 19 days was observed. Therefore a 24-day observation period is considered in suspected cases by the Chinese government and also by WHO [44-51]. The frequency of cases is increasing day by day, and it is essential to keep a check over it. Figure 4 gives a glance of confirmed cases cumulative and death overtime cumulative from 10 January onwards up to 25 May.

\section{Pathogenesis}

Like other CoVs, the SARS-CoV-2 is transmitted primarily via respiratory droplets and possible faeco-oral transmission routes [52]. Figure 5 gives a complete outline of the pathogenesis of coronavirus. On infection, primary viral replication is expected to occur in the mucosal epithelium of the upper respiratory tract with further multiplication into the lower respiratory tract and GI mucosa, giving rise to mild viremia. The virus enters the host cells through two methods either:

\section{Direct entry}

II. Endocytosis

These are positive sense ss-RNA viruses that can cause respiratory, enteric, hepatic, and neurologic diseases. High binding capacity with SARS-CoV-2 was observed by molecular biological analysis [53]. The ACE2 gene encodes the angiotensin-converting enzyme- 2 receptor for both the SARS-CoV and the human respiratory coronavirus NL63. Recent studies show that ACE2 could be the host receptor for the novel coronavirus 2019-nCoV/ SARS-CoV-2 [54].

Human angiotensin-converting enzyme 2 (hACE2), which was the binding receptor of SARS-CoV, is analogous to SARS-CoV-2. These hACE2 are type 1 membrane proteins expressed in various cells of the nasal mucosa, lung, bronchus, heart, kidney, intestines, bladder, stomach, 


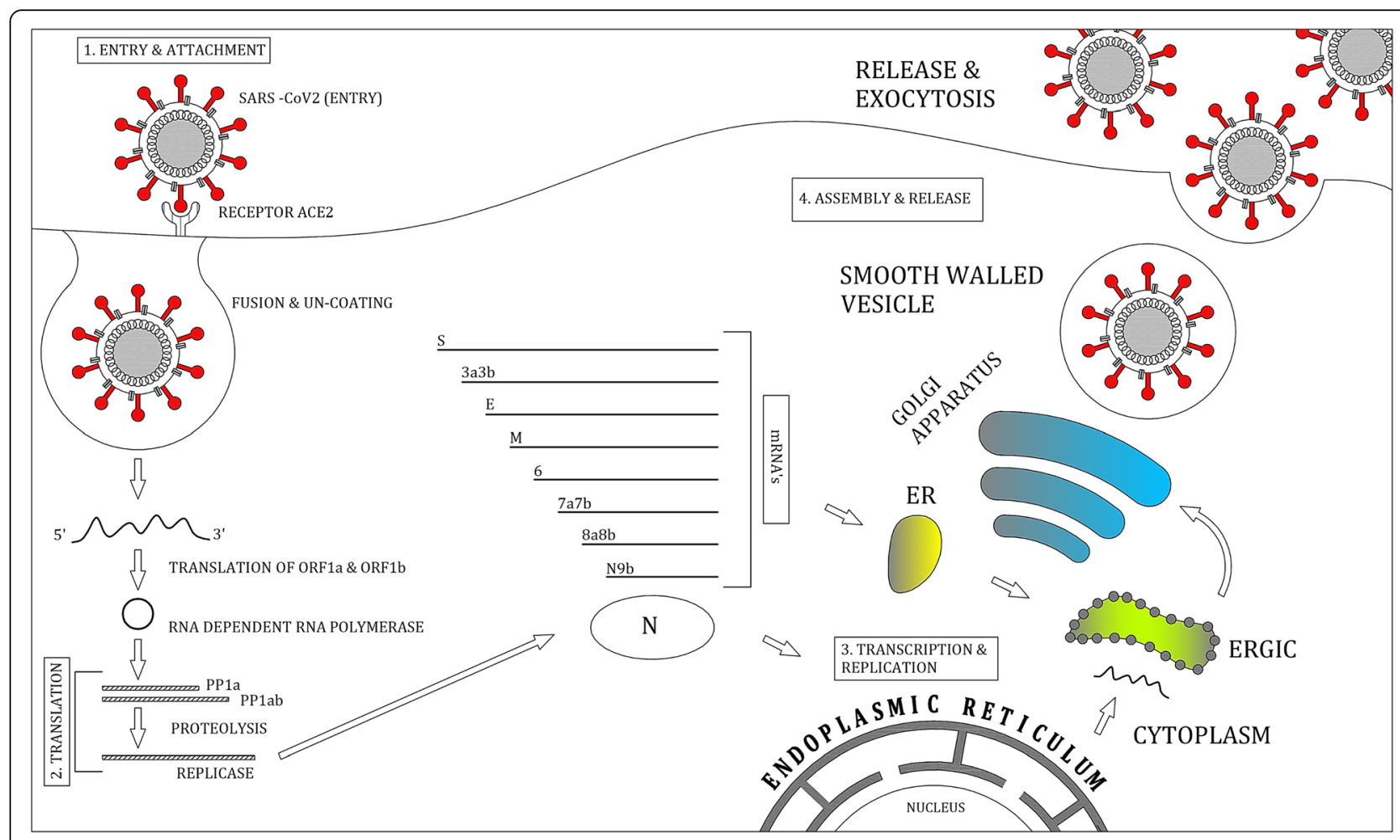

Fig. 3 Lifecycle of coronavirus

esophagus, and ileum. It functions as an enzyme in the RAS and is, therefore, mainly associated with cardiovascular diseases [55].

The zinc peptidase ACE2 has also expressed in the alveolar type 2 pneumocytes, which explains its role in lung damage due to SARS-CoV. The SARS-CoV-2 shows 10-12-fold more affinity towards the proteins than the other SARS-CoV. Pathophysiology and virulence of the virus link to the function of its nsps and structural proteins. The nsp can block the host's innate mechanism response while the virus envelope increases the pathogenicity as it assists the assembly and release of the virus [56].

The CoV spike glycoproteins comprise of three segments-a large ectodomain, a single-pass transmembrane anchor, and a small intracellular tail. The ectodomain is composed of the receptor-binding domain (RBD) - the S1 and the membrane fusion subunit S2. The two significant areas in s1, N-terminal domain (NTD) and the c-terminal domain (CTD), have been identified. The S1 NTDs are essential for binding to the sugar receptors, and the s1 CTDs are responsible for binding receptors ACE2, SPN, and DPP4 [57]. The S proteins undergo a considerable structural rearrangement to fuse with the viral membrane of the host cell membrane. The s1 subunit shedding and the s2 subunit transition to a highly stable conformation is the initial step in the fusion process [58]. The ACE2 consists of the $\mathrm{N}$-terminal peptidase domain (NPD) and the C-terminal collectrin-like domain (CCTD) that ends with a single transmembrane helix and a 40 residue intracellular segment. It provides a direct binding site for $\mathrm{S}$ protein of CoVs.

The enzymes which assist this virus attachment include the serine protease enzymes TMPRSS2. These enzymes, which are cell-surface proteases, facilitate entry. In endosomes, the $\mathrm{S} 1$ of s proteins is cleaved, and the fusion peptides S2 are exposed. This exposed S2 unit brings the HR1 and HR2 together, resulting in membrane fusion and thereby release of viral package into the host membrane [59].

The viral RNA enters the nucleus for replication after the viral contents are released. Viral mRNA is used to make viral proteins. Decreased expression of ACE2 in a host cell results in an attack on the airway epithelium by the virus. These lead to acute lung injury that triggers immune responses. The release of various pro-inflammatory and chemokines like IL-6, IFN- gamma, MCPI 1, and IL10 leads to capillary permeability in alveolar sacs. Due to local inflammation in the lungs, the secretion of proinflammatory cytokines and chemokines increases into the blood circulation of the patient. It results in fluid filling and increased difficulty in the exchange of gases across the membrane. Viral replication and infection in airway 
Table 4 Incubation period of coronaviruses

\begin{tabular}{llll}
\hline $\begin{array}{l}\text { Coronavirus } \\
\text { strain }\end{array}$ & $\begin{array}{l}\text { Incubation } \\
\text { period }\end{array}$ & $\begin{array}{l}\text { Death } \\
\text { period }\end{array}$ & Symptoms \\
\hline SARS-CoV & $4-10$ days & $20-25$ days & $\begin{array}{l}\text { Fever, dry cough, myalgia, dyspnea, headache, sore throat, sputum production, rhinorrhea, } \\
\text { watery diarrhea, confusion, poor appetite. }\end{array}$ \\
MERS-CoV & $5-6$ days & $11-13$ days & $\begin{array}{l}\text { Myalgia, fever, chills, malaise associated with confusion, cough, shortness of breath, dyspnea, } \\
\text { pneumonia }\end{array}$ \\
COVID-19 & $3-7$ days & $17-24$ days & $\begin{array}{l}\text { Fever, cough, dyspnea, muscle ache, confusion, headache, sore throat, rhinorrhea, chest pain, } \\
\text { diarrhea, nausea, vomiting, anosmia, dysgeusia }\end{array}$ \\
\hline
\end{tabular}

On the basis of studies conducted and data findings, virologists points out that incubation period extends to 14 days, with a median time of 4-5 days from exposure to symptom onset. One study reported that $97.5 \%$ of persons with COVID-19 who develop symptoms will do so within 11.5 days of SARS-CoV-2 infection

epithelial cells could cause high levels of virus-linked pyroptosis with associated vascular leakage. IL-beta cytokine released during pyroptosis is a highly inflammatory form of programmed cell death, which is the trigger subsequent inflammatory response. The IgG antibodies against SARS$\mathrm{CoV}-2 \mathrm{~N}$ protein can be detected in the serum in the early stages at the onset of the disease. The non-neutralizing antibodies result in ADE (antibody-dependent enhancement), which leads to an increased systematic inflammatory response.

The pro-inflammatory cytokines and chemokines are an indicator of $\mathrm{T}_{\mathrm{H}}$ cells. Secretions from such cytokines and chemokines attract immune cell monocytes and $\mathrm{T}$ lymphocytes. High levels of pro-inflammatory cytokines, including IL-2, IL-7, IL-10, IP-10, G-CSF, MCP-1, MIP$1 \mathrm{~A}$, and TNF alpha, were detected in the severe infection called cytokine storm or cytokine release syndrome as a crucial factor in the pathogenesis of COVID-19.

The cytokine storm increases the inflammatory response resulting in increased blood plasma levels of neutrophils IL-6, IL-10, granulocytes, MCP1, TNF, and decreased organ perfusion, which results in multiple organ failure. Cytokine storm and pulmonary edema due to ACE2 dysregulation result in acute respiratory distress syndrome. SARS-CoV-2 can also affect the CNS [60]. Myocardial damage increases the difficulty and complexity of patient treatment [61]. Clinical investigations have shown that patients with cardiac diseases, hypertension, or diabetes, who are treated with ACE2increasing drugs, including inhibitors and blockers, are at higher risk of getting infected with SARS-CoV2 [62]. Death results due to ARDS and multiple organ failure.

\section{Symptoms}

People with COVID-19 infection show symptoms ranging from mild to severe illness. Figure 6 shows a brief outline of various symptoms related to COVID-19. The warning signs and symptoms such as trouble breathing, constant pain or pressure in the chest, inability to wake or stay awake, and bluish lips or face are observed in patients [63]. Older people (65 years and older) are at higher risk of developing the disease.
According to a study, people of all ages having asthma, diabetes, HIV, liver diseases, severe heart conditions, severe obesity (body mass index [BMI] of 40 or higher), and chronic kidney diseases undergoing dialysis show a higher mortality rate. The other populations with people showing disabilities, pregnancy, and breastfeeding and people experiencing homelessness, racial, and minority groups are at elevated risk of transmission of disease [64]. The crucial fact to know about coronavirus on surfaces is that they can easily be cleaned with ordinary household disinfectants that will kill the virus [65]. Studies have shown (Fig. 7) that the COVID-19 virus can survive for up to $72 \mathrm{~h}$ on plastic and stainless steel, about $4 \mathrm{~h}$ on copper, and less than $24 \mathrm{~h}$ on cardboard [66].

\section{Diagnosis: COVID-19}

There are two categories of tests available for COVID-19:

- Viral tests: a viral analysis indicates whether a person has a current infection.

- Antibody tests: an antibody indicates whether a person had an infection.

The protection of getting infected again in a person showing the presence of antibodies to the virus is still unexplained [67].

\section{Tests for current infection}

A swab sample is collected (from the nose) to conclude that a person is currently infected with SARS-CoV-2. Some tests are called as point-of-care tests, which means their results may be available in less than an hour. Other test takes 1-2 days for analyzing after being received by the laboratory [68].

\section{Test for past infection}

Antibody tests analyze a blood sample for the presence of antibodies, which show if one had a previous infection with the virus. Antibody tests cannot be used to diagnose someone as being currently infected with COVID19. Antibody tests are accessible through healthcare providers and laboratories [69]. In severe cases, clinical diagnosis is done based on the clinical manifestations of 


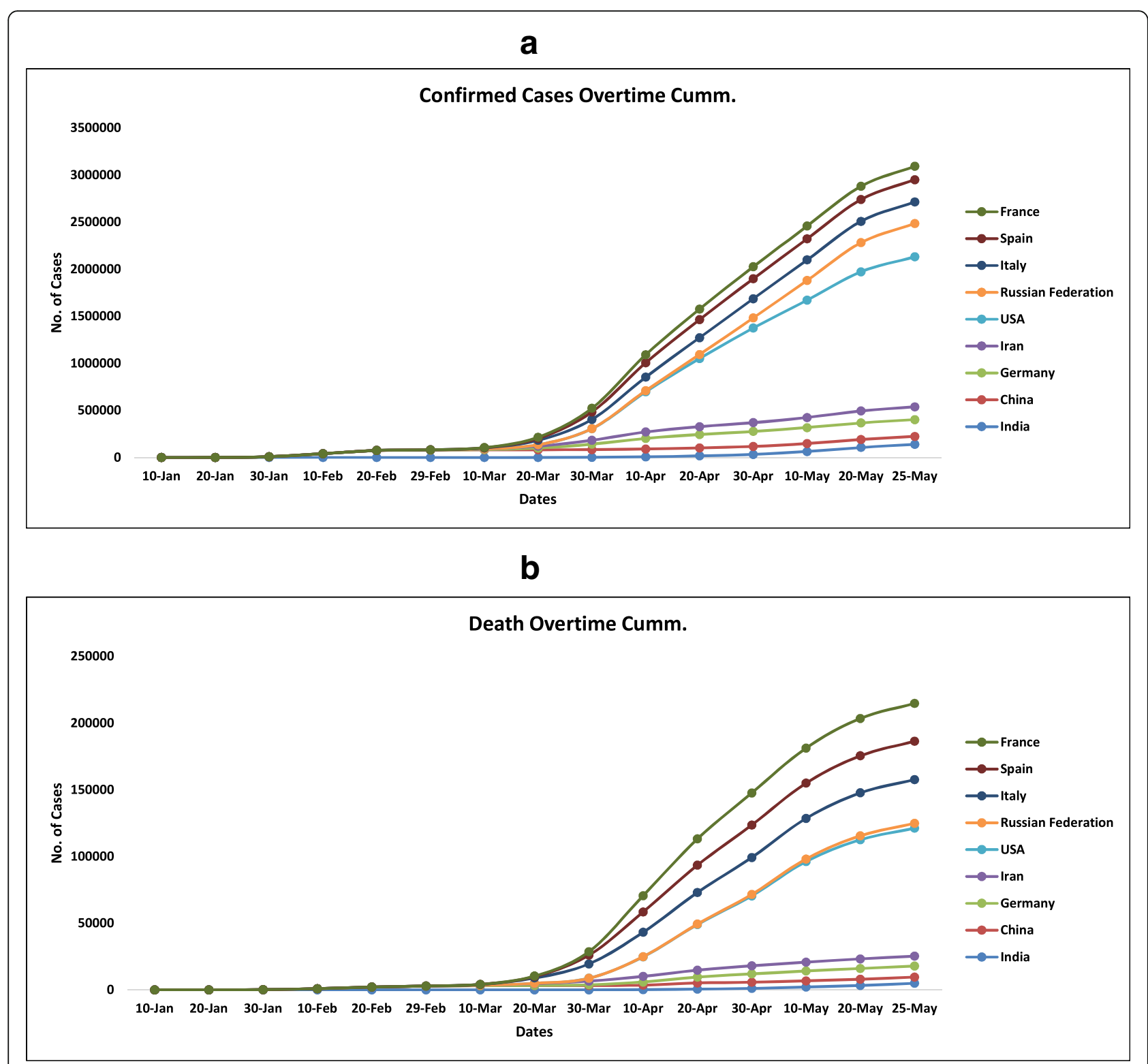

Fig. 4 a Graph of confirmed (cumulative) cases overtime in various countries. b Graph of death (cumulative) overtime in various countries

respiratory failure syndrome, increased liver function tests, blood tests indicating leukopenia, and high levels of ferritin. For such, a test for soluble CD-163 (sCD163), showing the activation of macrophages, was suggested [70]. Laboratory diagnosis included genomic sequencing, reverse-transcription polymerase chain reaction (RT-PCR), and serological methods (such as enzyme-linked immunoassay [ELISA]). Because of the rapidly changing diversity found in the expression of the novel coronavirus, pneumonia became diverse and quickly changed. Other methods used are radiographic images for early observations and evaluation of disease severity [71].
Reverse-transcription polymerase chain reaction (RTPCR) shows high sensitivity for new SARS cases. The suspected cases must be confirmed by using RT-PCR and other methods (slower methods) of detection such as serology or viral culture, isolation, and identification by electron microscopy, thereby causing a significant increase in the time required for an accurate diagnosis [72]. The samples are collected from upper and lower respiratory tracts through expectorated sputum, bronchoalveolar lavage, or endotracheal aspirate, which are then assessed by conducting polymerase chain reaction for viral RNA. It is recommended to repeat the test for reevaluation purposes in case of a positive result, and if 


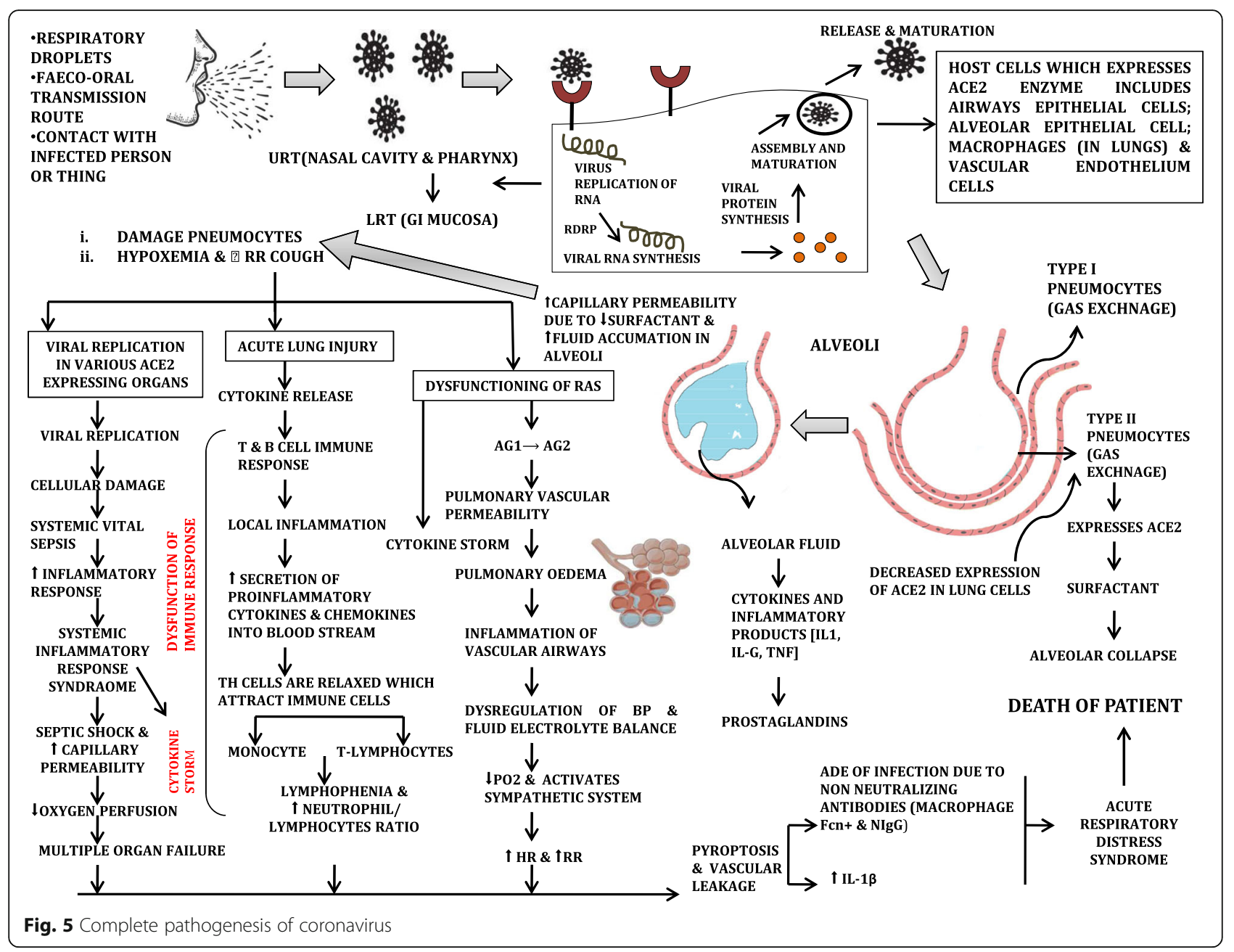

the test is negative, a strong clinical impression also permits repeat testing [73].

An alternative diagnostic test to detect the SARS-CoV is mass spectroscopic identification of microbial nucleic acid signatures. Computed tomography images of the lungs showed $100 \%$ multiple patchy with fine mesh and consolidated shade distributed under the pleura. Nucleic acid tests were conducted in 187 patients, and all were positive to SARS-CoV-2. In the pulmonary CT images, $8 \%$ of them (15 cases) showed diffused lesions in either lungs or white lung. In the absorptive period, 98.9\% showed fibrogenesis and diminished lesions. The CT imaging features differed from each follow-up showing different clinical symptoms [74]. The improvement in the detection of COVID-19 was found by the ELISA method. It is based on SARS $\mathrm{r}-\mathrm{CoV} \mathrm{Rp} 3$ nucleocapsid protein, which helps to detect the IgM and IgG against SARS-CoV-2. ELISA is a highly recommended method as the sampling blood is less stringent, and antibodies allow longer windows than oropharyngeal swabs for detecting viruses [75].

\section{Treatment}

There is no particular treatment recommended for COVID-19. There is no data obtained regarding prophylactic treatment for COVID-19, only we can prevent from coming in contact with the pathogen. Confirmed cases are hospitalized and admitted in the same ward. Patients with mild symptoms may not require hospitalization [76]. They are isolated or self-isolated at home by following the doctor's advice. Critically ill patients (respiratory shock, respiratory failure, septic shock, or other organ failures) should be admitted to ICU as soon as possible [77].

\section{General treatment}

The general treatment includes bed rest and supportive measures ensuring sufficient intake of calories, fluid, and electrolytes, and maintenance of acid-base homeostasis. Monitoring oxygen saturation and vital signs, keeping the respiratory tract unobstructed and inhaling oxygen, measuring C-reactive protein, hematology and biochemistry laboratory testing and ECG, blood gas analysis, and examining of chest images as when required and 


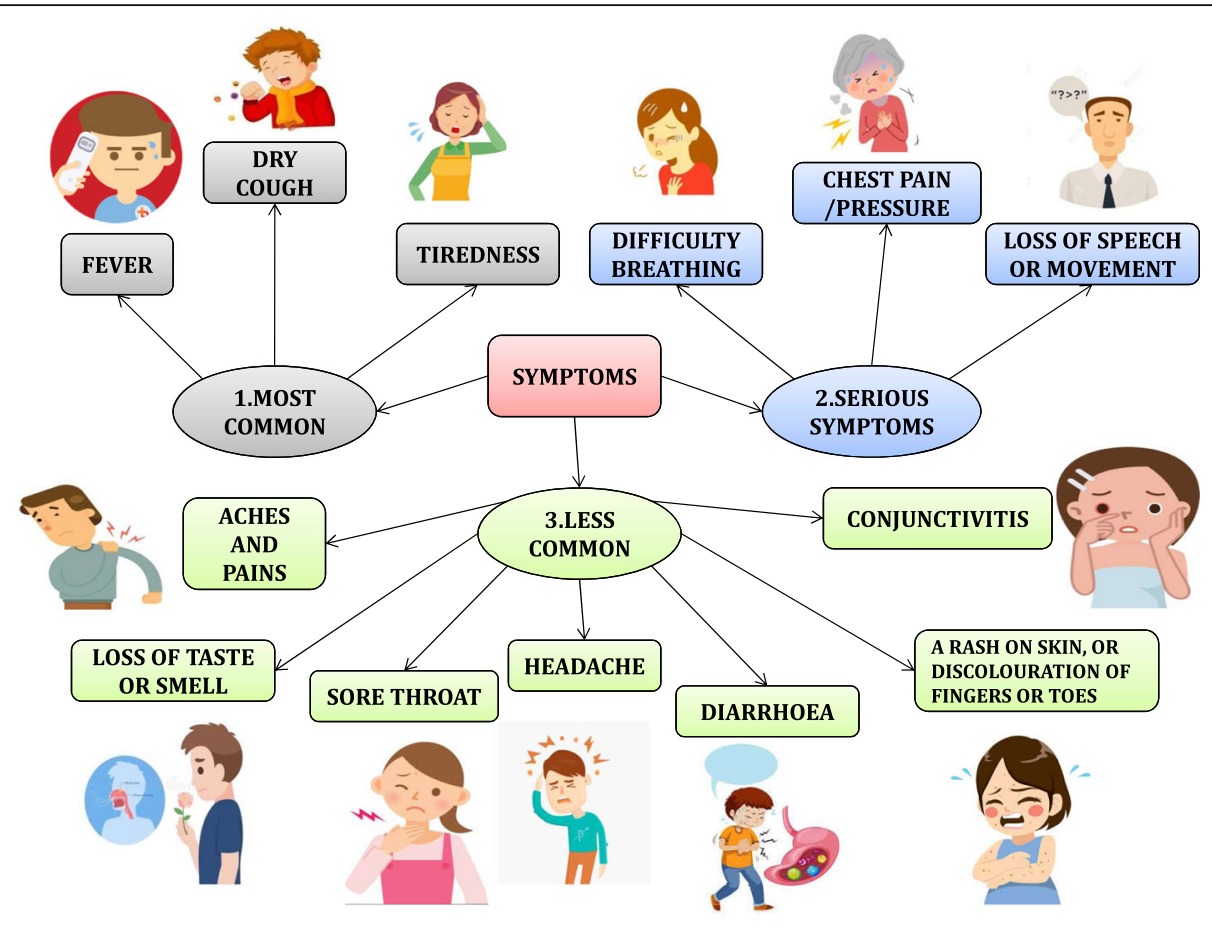

How long can SARS-COV-2 survive on surfaces

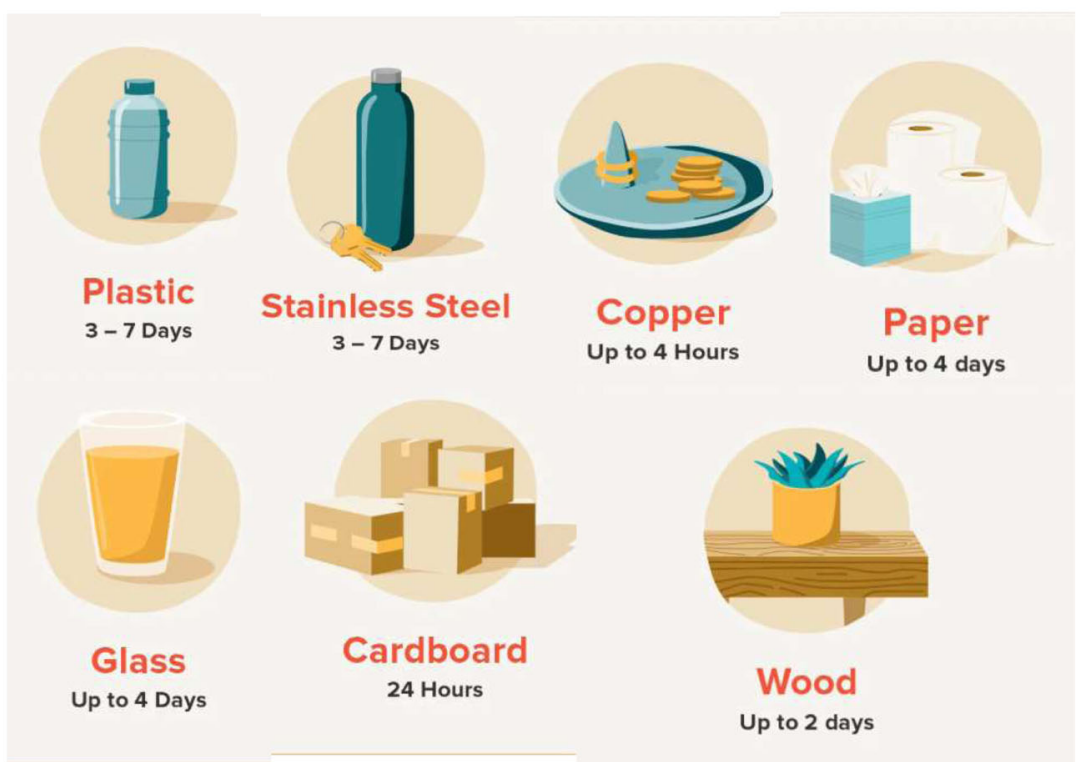

Fig. 6 Symptoms for coronavirus

monitoring for any complications [78]. Patients having high body temperature above $38.5^{\circ} \mathrm{C}$ Celsius are administered with ibuprofen and acetaminophen orally.

\section{Oxygen therapy}

Patients with conditions of obstructed breathing, respiratory distress, shock, coma, and convulsions must receive oxygen therapy and airway management, targeting $\mathrm{SpO} 2$ more significant than $94 \%$. Initiate $\mathrm{O}_{2}$ treatment at $5 \mathrm{~L} /$ min and titrated to reach the target or use a face mask with a reservoir bag $(10-15 \mathrm{~L} / \mathrm{min})$ if the patients are in critical condition.

Once stable, the target is $90 \% \mathrm{SpO} 2$ in non-pregnant adults and $95 \%$ in pregnant adults. The use of nasal prongs or nasal cannula is preferred in young children, as they may be better tolerated. When oxygen therapy 


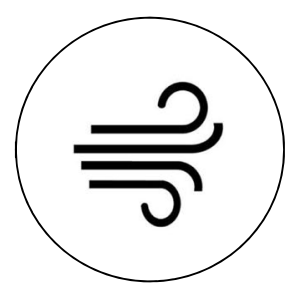

IN AIR (UPTO 3 HOURS)

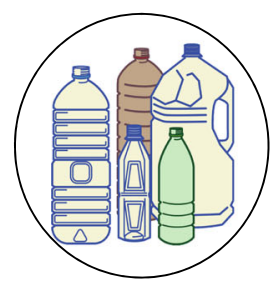

PLASTIC (3-7 DAYS)

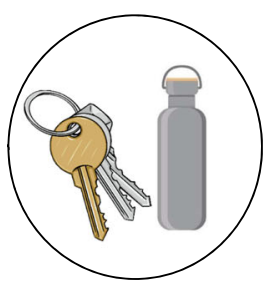

STAINLESS STEEL (3-7 DAYS)

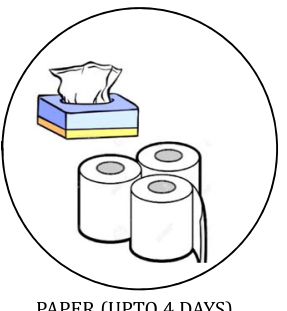

PAPER (UPTO 4 DAYS)
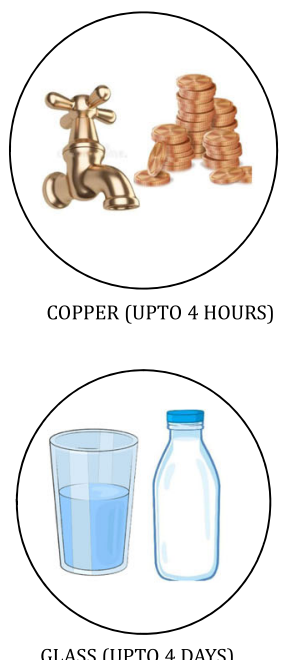

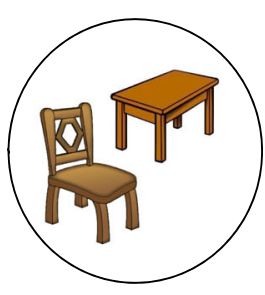

WOOD (UPTO 2 DAYS)

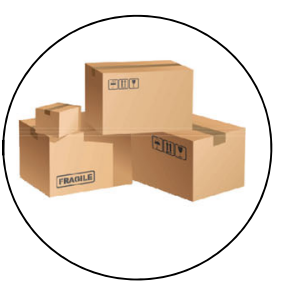

CARDBOARD (UPTO 24 HOURS)

Fig. 7 Survival of virus on various objects

fails, mechanical ventilation is necessary. In a metaanalysis, the use of additional oxygen therapy (38.9\%), non-invasive $(7.1 \%)$ and invasive ventilation $(28.7 \%)$, and even ECMO (0.9\%) was surprisingly high among the 1876 patients in which any kind of pharmacological and supportive intervention was reported [79].

\section{Drugs}

Antiviral agents Remdesivir inhibits virus infection at the micromolar level $(0.77-1.13 \mu \mathrm{M})$ and with high selectivity [80]. Remdesivir gets incorporated into viral RNA due to its adenosine analog nature and results in premature chain termination [81]. Remdesivir is not approved by the Food and Drug Administration (FDA). It is only recommended for mild or moderate COVID-19 conditions and the treatment of hospitalized adults and children in emergencies.

Chloroquine/hydroxychloroquine Chloroquine increases endosomal $\mathrm{pH}$, making the environment unfavorable for viral cell fusion. It also affects the glycosylation process of ACE-2. On administering chloroquine after $1 \mathrm{~h}$ of infection, gradual loss of antiviral activity was seen, though it affects the endosome fusion when administered shortly after the infection. When administered after $3-5 \mathrm{~h}$ after the infection, chloroquine was significantly effective against $\mathrm{HCoV}$ strain OC43 [82]. There is an excessive risk of toxicities due to high chloroquine doses; the recommended dose for chloroquine is $600 \mathrm{mg}$ twice daily for 10 days for the treatment of COVID-19.

Interferon-alpha Interferon- $\alpha$ is used in treating bronchiolitis; viral pneumonia; acute upper respiratory tract infection; hand, foot, and mouth disease; SARS; and other viral infections in children. According to the clinical research and experiences, the following usage is recommended for COVID-19

1. Interferon- $\alpha$ nebulization: interferon- $\alpha 200,000-$ $400,000 \mathrm{IU} / \mathrm{kg}$ or $2-4 \mu \mathrm{g} / \mathrm{kg}$ in $2 \mathrm{~mL}$ sterile water, nebulization two times per day for $5-7$ days

2. Interferon- $\alpha 2 b$ spray: applied for high-risk populations with close contact with suspected COVID-19 infected patients or those in the early phase with only upper respiratory tract symptoms.

Lopinavir/ritonavir In a clinical trial among adult patients of or less than 18 years, it was observed that a combination of lopinavir/ritonavir, ribavirin, and interferon beta-1b would speed up the recovery, suppress the viral load, shorten hospitalization, and reduce mortality compared with lopinavir/ritonavir [83].

Immune-based therapy Patients who show an inadequate response to initial therapy can get benefit from immunoglobulin [84]. Non-SARS-CoV-2-specific IVIG should not be used for COVID-19 except in case of clinical trials.

Corticosteroids Corticosteroids are widely used in the symptomatic treatment of severe pneumonia. According to a detailed review and analysis, the result indicates that patients with severe conditions required corticosteroid therapy [85]. According to a systematic review of literature, daily use of corticosteroids in a COVID-19 patient is not encouraged; however, some studies suggest that methylprednisolone can reduce the mortality rate in more severe conditions, such as in ARDS [86]. 
Antimicrobial therapy Patients with a mild type of bacterial infection can take oral antibiotics, such as cephalosporin or fluoroquinolones. Although a patient may be a suspect for COVID-19, appropriate antimicrobial agent should be administered within an hour of recognition of sepsis. Antibiotic therapy should be based on the clinical diagnosis of community-acquired pneumonia, healthcare-associated pneumonia, local epidemiology, susceptibility data, and national treatment guidelines. When there is the ongoing local circulation of seasonal influenza, this therapy with a neuraminidase inhibitor should be considered for the treatment for patients [87].

Tocilizumab According to a review, 25 patients with laboratory-confirmed severe COVID-19 who received tocilizumab and completed 14 days of follow-up, 36\% were discharged alive from the intensive care unit, and $12 \%$ died [88]. The biopsy specimen analysis suggested that increased alveolar exudates resulted from an immune response against an inflammatory cytokine storm. Probably an obstruction in alveolar gas exchange contributed to the high mortality rate of severe COVID-19 patients. A study identified that pathogenic $\mathrm{T}$ cells and inflammatory monocytes arouse an inflammatory storm with a large amount of interleukin 6 . Tocilizumab blocks IL-6 receptors, which shows encouraging clinical results, including controlling temperature quickly and improved respiratory functions. Henceforth, tocilizumab is useful in the treatment of severe COVID-19 patients to calm the inflammatory storm and reduce mortality [89].

Ivermectin FDA-approved drug ivermectin for parasitic infection has a possibility for reprocessing and acts as an inhibitor of SARS-CoV-2 in vitro. A single therapy can affect approximately 500-fold reduction and effectual loss of substantially all viral material by $48 \mathrm{~h}$ [90]. A single of ivermectin, in combination with doxycycline, yielded the near-miraculous result in curing the patients with COVID-19 virtually.

Azithromycin Azithromycin is used for patients with viral pneumonia from COVID-19. It can also work synergistically and coactively with other antiviral treatments. It has also shown antiviral activity against the Zika virus and rhinoviruses, which cause the common cold. Viral infection was significantly reduced in patients receiving hydroxychloroquine than those who did not. The virus elimination was efficient in patients who received both azithromycin and hydroxychloroquine [91]. (Table 5) lists other supporting agents used in treatment [92].

\section{Discussion}

\section{Precautions and preventions}

WHO declared the COVID-19 outbreak as a public health emergency of international concern on 30 January 2020. Unfortunately, no medication until now is approved by the FDA, and various trials are going on. Still, the most effective weapon the community has in hand is the prevention of spread. The following are some of the COVID-19 prevention measures.

- Quarantine: self-quarantine, mandatory quarantine (private residence, hospital, public institution, etc.)

- Other measures: avoiding crowding, hand hygiene, isolation, personal protective equipment, school/ workplace measures/closures, social distancing [93].

Asymptomatic carriers as the "silent spreaders" are of great concern for the elimination of disease and its control. So, more attention should be given to them [94]. Hand hygiene with alcohol-based hand-rub is globally recommended as productive and economical procedures against SARS-CoV-2 cross-transmission [95]. The economic implications of hand hygiene have been established. It has been found that this cost under $1 \%$ of total HAI-related economics. It is better to invest not only in the materials needed but also in the people working there. This investment will lead to an increase in the health outcome [96]. The clinical presentation of COVID-19 is non-specific, so it needs a robust and accurate diagnosis. It has been suggested that before stopping the infection control measures, we have to be sure to exclude the diagnosis [97]. Prevention plays a vital role in treating and defeating the COVID-19 disaster.

The Centers for Disease Control and Prevention gives standard precautions (Fig. 8) and recommends measures to prevent COVID-19. Wear personnel protective equipment (face shield, mask, gown, gloves, and closed-toed shoes) when evaluating persons at risk. N-95 masks are known to prevent up to $95 \%$ of small particles, including viruses [98]. Cover all coughs/sneezes with a tissue and then throw the tissue away. Regularly clean/disinfect frequently touched objects and surfaces with household cleaning spray and use a tissue when handling (e.g., doorknobs, sink taps, water fountain handles, elevator buttons, cross-walk buttons, and shopping carts). Avoid contact with infected people (recommended $>6 \mathrm{ft}$ ) and maintain an appropriate distance as much as possible and refrain from touching nose eyes and mouth [99]. Avoid well persons when you are ill. Wear a mask continuously if taking care of persons with respiratory illness. To turn on the tap, use a paper towel and then wash hands with soap and water for at least $30 \mathrm{~s}$ after going to the bathroom. Use hand sanitizer and carry whenever at a public venue. Activate community-based 
Table 5 Supporting agents used in treatment

\begin{tabular}{|c|c|c|}
\hline Antiviral agents & Supporting agents & Others \\
\hline $\begin{array}{l}\text { - Baloxavir } \\
\text { - Chloroquine phosphate } \\
\text { - Favipiravir } \\
\text { - HIV protease inhibitors } \\
\text { - Hydroxychloroquine } \\
\text { - Neuraminidase inhibitor } \\
\text { - Remdesivir } \\
\text { - Umifenovir }\end{array}$ & 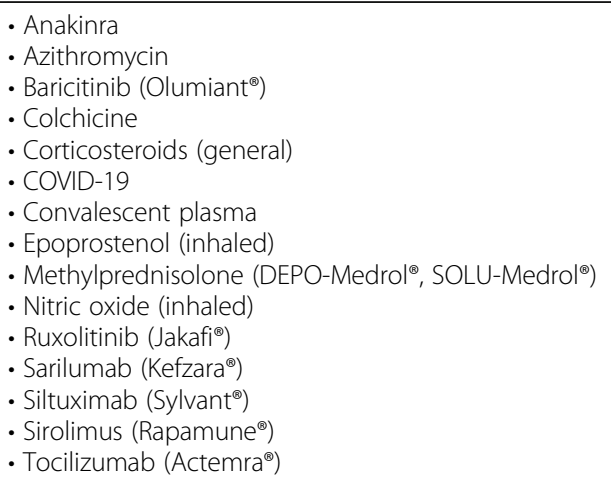 & $\begin{array}{l}\text { - ACE inhibitors, angiotensin II receptor blockers (ARBs) } \\
\text { - Anticoagulants (low molecular weight heparin [LMWH], } \\
\text { unfractionated heparin [UFH]) } \\
\text { - Famotidine } \\
\text { - HMG-CoA reductase inhibitors (statins) } \\
\text { - Immune globulin (IGIV, IVIG, Y-globulin) } \\
\text { - Ivermectin } \\
\text { - Nebulized drugs } \\
\text { - Niclosamide } \\
\text { - Nitazoxanide } \\
\text { - Nonsteroidal anti-inflammatory agents (NSAIDs) } \\
\text { - Tissue plasminogen activator (t-PA; alteplase) }\end{array}$ \\
\hline
\end{tabular}

The repurposing of available therapeutic drugs is being used as supporting agents in the treatment of COVID-19; however, the efficacy of these treatments should be verified by using designed clinical trials

interventions (e.g., cancel sporting events, dismiss, termination of universities and schools, practice social distancing, create employee plans to work remotely) [100]. Create a household-ready plan. Cancel any non-essential travel [101]. Frequent disinfection and cleaning are advised for groups that are at risk of contracting the virus [102].

In an Indian study mathematical approach was used to address some questions related to intervention strategies to control the COVID-19 transmission in India. Some hypothetical epidemic curves helped to illustrate the critical findings [103]. Predication of spread and implications of prevention and control using the Maximum-Hasting
$(\mathrm{MH})$ parameter assessment method and the modified Susceptible Exposed Infectious Recovered (SEIR) model was done. Suppression, mitigation, and mildness were the three predicted outlines for the spread of infection in some African countries [104].

Infection control strategies that can be acquired in hospitals were accomplished in a Taiwanese hospital to tackle the COVID-19 pandemic. These included emergency vigilance and responses from the hospital administration, education, surveillance, patient flow arrangement, the partition of hospital zones, and the prevention of a systemic shutdown by using the "divided cabin, divided flow"

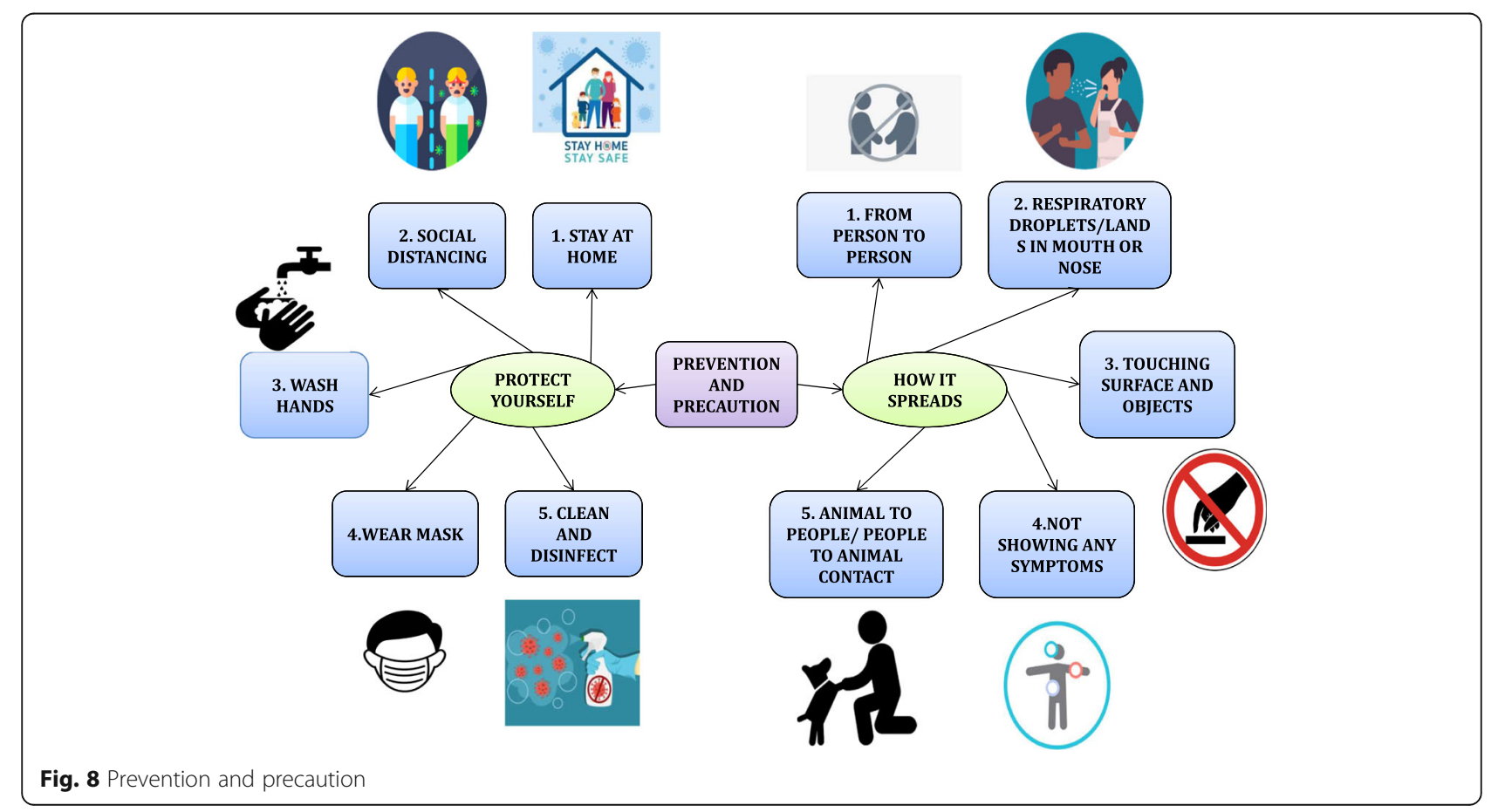


strategy. These measures may not be universally appropriate [105]. The preventive measures implemented in China included countrywide health education campaigns. The Examine and Approve Policy on the continuation of work, working and living quarters, a health Quick Response code system, community screening, and social distancing policies were some of the preventive measures [106].

Based on the analysis of immigration population data, the Epidemic Risk Time Series Model was outlined to estimate the effectiveness of COVID-19 epidemic control and prevention among different regions in China. Compared to other methods, this model was able to issue early recognition more instantaneously. For the prevention and control of COVID-19, this model can be generalized and applied to other countries [107]. The majority of clinical trials involving COVID-19 vaccines or treatment are showing encouraging results. (Tables 6 and 7) show ongoing phase 3 and 4 clinical trials [108].

\section{Impact of COVID-19 on overall health of the people worldwide}

The international response to COVID-19 has been more transparent and efficient when compared to the SARS outbreak [109].

The pandemic COVID-19, being a most severe strainer, is affecting the overall health system worldwide. There is a continuously increasing demand for healthcare facilities and associated workers, which is overstretching the ability to operate efficiently [110]. Some pieces of evidence are showing a destructive effect on maternal and child health. Some financial, educational, sanitation, and even clinical constraints are threatening the overall population of the children [111]. As coronavirus is sweeping across the world, the primary psychological impact is elevated in terms of stress and anxiety. The quarantine period is expected to raise cases involving suicidal behavior, substance abuse, self-harm, depression, and loneliness. WHO Department of Mental Health and Substance use has given some messages to overcome psychological impacts [112]. There is a relationship between human development and infectious diseases. Whichever changes (new technology, constructions of dams, deforestations, migration, increasing populations, the emergence of urban ghettoes, globalization of food, and increasing international travel) brought about by the development, are stretching the word into the mouth of such pandemics indirectly. This pandemic is having a significant impact on the global economy as the erosion of capacity and rise in poverty $[113,114]$.

COVID-19 has affected the population differently based on gender. Significantly, this crisis is affecting the reproductive and sexual health of women. Another point is that there should be an equal contribution to both the genders in any healthcare body. There should be more distribution of decision-making power among them [115]. Protective measures can effectively prevent COVID-19 infection, including improving personal hygiene, wearing N95 masks, adequate rest, and proper ventilation [116].

\section{Have to learn to live with COVID-19}

The Health Ministry has said that we have to learn to survive with COVID-19. We cannot step ahead by carrying the burden of COVID-19 that could recur annually and kill so many people [117]. Governments are learning to strike a balance between controlling COVID-19 spread and allowing individual freedoms and economic activity. Measures such as lockdowns, arbitrary travel bans, widespread quarantines, intrusive screening of people crossing boundaries can be adopted for prevention. Virtual work will become much more common. Supplier close-downs, sudden employee truancy, and demand collapse caused by disease outbreaks will make the businesses able to withstand disruptions.

The government, industry, or specialist certification for disease control processes and standards similar to ISO 9001 or USFDA certificate will be a crucial part of many businesses. The cost of traveling will expand more due to the risk of infection and lockdown. At the same time, the responsibility of work airlines, hotels, and restaurants will be added to minimize infection risk. Delivery businesses will perform well, and "Contactless delivery" is already a thing.

The industries that provide products to help circumvent, control, diminish, or treat COVID-19 will flourish. The requirement for hospital rooms will increase tremendously, with an increasing need for reserves of equipment, supplies, and drugs. In the upcoming time, businesses are likely to face demand crisis as the world comes to terms with living in a state of medical beleaguerment [118]. It is just a prediction, but we can still aspire for the best [119]. The most destructive effects would be in countries with weak health systems, ongoing disputes, or existing infectious disease epidemics.

In contrast, the health systems in high-income countries would be stretched out by the outbreak [120]. It has been seen that resources are limited in countries with poor scientific infrastructure, such as Nepal, where there was only one laboratory equipped to test for coronavirus infection. Fear and stigma is an evident feature of the COVID-19; it has affected the economic and social development of many countries worldwide [121].

The insufficiency of the trained workforce capable of performing experiments required to test for SARS-CoV-2 and interpret the results is another major limitation in the testing and confinement of COVID-19 in developing countries [122]. The virus has the potential to adapt and get through the different environmental conditions, which makes it 
Table 6 Ongoing clinical trials phase 3 studies

\begin{tabular}{|c|c|c|c|}
\hline Study title & Conditions & Interventions & Locations \\
\hline Randomized evaluation of COVID-19 therapy & $\begin{array}{l}\text { Severe acute respiratory } \\
\text { syndrome }\end{array}$ & $\begin{array}{l}\text { Drugs: hydroxychloroquine, } \\
\text { lopinavir/ritonavir, } \\
\text { corticosteroid, azithromycin, } \\
\text { tocilizumab }\end{array}$ & $\begin{array}{l}\text { Nuffield Department of Population } \\
\text { Health, University of Oxford, Oxford, UK }\end{array}$ \\
\hline $\begin{array}{l}\text { Hydroxychloroquine and zinc with either } \\
\text { azithromycin or doxycycline for treatment of } \\
\text { COVID-19 in outpatient setting } N\end{array}$ & COVID-19 & $\begin{array}{l}\text { Drugs: hydroxychloroquine, } \\
\text { azithromycin, zinc sulfate, } \\
\text { doxycycline }\end{array}$ & St. Francis Hospital, Roslyn, NY, USA \\
\hline Favipiravir in hospitalized COVID-19 patients & COVID-19 & $\begin{array}{l}\text { Drugs: favipiravir, } \\
\text { hydroxychloroquine }\end{array}$ & $\begin{array}{l}\text { Shahid Modarres Hospital, Shahid } \\
\text { Beheshti University of Medical Sciences } \\
\text { and Health Services, Tehran, } \\
\text { Iran }\end{array}$ \\
\hline Baricitinib therapy in COVID-19 & COVID-19 pneumonia & $\begin{array}{l}\text { Drug: baricitinib } 4 \mathrm{mg} \text { oral } \\
\text { tablet }\end{array}$ & Fabrizio Cantini, Prato, Tuscany, Italy \\
\hline $\begin{array}{l}\text { Treatment for COVID-19 in high-risk adult } \\
\text { outpatients }\end{array}$ & COVID-19 SARS-CoV-2 & $\begin{array}{l}\text { Drugs: ascorbic acid, } \\
\text { hydroxychloroquine sulfate, } \\
\text { azithromycin, folic acid }\end{array}$ & $\begin{array}{l}\text { - Boston University, Boston, MA, USA } \\
\text { - University of Washington } \\
\text { Coordinating Center, Seattle, } \\
\text { Washington, USA } \\
\text { - UW Virology Research Clinic, Seattle, } \\
\text { WA, USA and } 4 \text { more }\end{array}$ \\
\hline $\begin{array}{l}\text { Convalescent plasma for hospitalized adults } \\
\text { with COVID-19 respiratory illness (CONCOR-1) }\end{array}$ & COVID-19 & Other: convalescent plasma & $\begin{array}{l}\text {-Vancouver General Hospital, } \\
\text { Vancouver, British Columbia, Canada } \\
\text { - Victoria General Hospital, Victoria, } \\
\text { British Columbia, Canada } \\
\text { - London Health Sciences Centre-- } \\
\text { University Hospital, London, Ontario, } \\
\text { Canada and } 25 \text { more }\end{array}$ \\
\hline $\begin{array}{l}\text { BCG vaccine for health care workers as } \\
\text { defense against COVID-19 }\end{array}$ & $\begin{array}{l}\text { Coronavirus infection, } \\
\text { Coronavirus as the cause } \\
\text { of diseases classified } \\
\text { elsewhere }\end{array}$ & $\begin{array}{l}\text { Biologicals: BCG vaccine, } \\
\text { placebo vaccine }\end{array}$ & $\begin{array}{l}\text { - Harvard T.H. Chan School of Public } \\
\text { Health, Boston, MA, USA } \\
\text { - Baylor College of Medicine, Houston, } \\
\text { TX, USA } \\
\text { - MD Anderson Cancer Center, Houston, } \\
\text { TX, USA and } 4 \text { more }\end{array}$ \\
\hline $\begin{array}{l}\text { Outcomes related to COVID-19 treated with } \\
\text { hydroxychloroquine among in-patients with } \\
\text { symptomatic disease }\end{array}$ & $\begin{array}{l}\text { Coronavirus acute } \\
\text { respiratory infection } \\
\text {-SARS-CoV infection }\end{array}$ & $\begin{array}{l}\text { - Drugs: hydroxychloroquine, } \\
\text { placebo }\end{array}$ & $\begin{array}{l}\text { - Stanford University, Stanford, CA, USA } \\
\text { - University of Colorado Hospital, Aurora, } \\
\text { CO, USA } \\
\text { - Denver Health Medical Center, Denver, } \\
\text { CO, USA and } 40 \text { more }\end{array}$ \\
\hline $\begin{array}{l}\text { Treatment of COVID-19 patients with anti- } \\
\text { interleukin drugs }\end{array}$ & COVID-19 & $\begin{array}{l}\text { - Other: usual care } \\
\text { - Drugs: anakinra, siltuximab, } \\
\text { tocilizumab }\end{array}$ & $\begin{array}{l}\text { - University Hospital Saint-Pierre, } \\
\text { Brussels, Belgium } \\
\text { - University Hospital Antwerp, Edegem, } \\
\text { Belgium } \\
\text { - University Hospital Brussels, Jette, } \\
\text { Belgium } 13 \text { more }\end{array}$ \\
\hline $\begin{array}{l}\text { Study to evaluate the safety and antiviral } \\
\text { activity of remdesivir (GS-5734 }{ }^{\mathrm{TM}} \text { ) in } \\
\text { participants with severe coronavirus disease } \\
\text { (COVID-19) }\end{array}$ & COVID-19 & Drug: remdesivir & $\begin{array}{l}\text { - Kaiser Permanente Los Angeles } \\
\text { Medical Center, } 3340 \text { E. La Palma } \\
\text { Avenue, Anaheim, CA, USA } \\
\text { - Alta Bates Summit Medical Center, } \\
\text { Berkeley, CA, USA } \\
\text { - Mills-Peninsula Medical Center, } \\
\text { Burlingame, CA, USA and180 more }\end{array}$ \\
\hline
\end{tabular}

quite difficult to identify its mode of survival [123]. Another crucial impediment in a research project is a suitable model to investigate in vivo mechanism associated with the pathogenesis of SARS-CoV-2 [124-126].

Current screening approaches for COVID-19 are likely to miss approximately $50 \%$ of the infected cases, even in countries with sound health systems and available diagnostic capacities. Many symptoms correlated with
COVID-19 are similar to malaria, such as fever, difficulty in breathing, fatigue, and headaches of acute onset. If symptoms alone are used to specify a case during the emergency period then, a malaria case may be misinterpreted as COVID-19. The symptoms for malaria are seen within 10-15 days after an infective bite; multi-organ failure is common in severe cases among adults, while respiratory distress is also expected in children [127]. 
Table 7 Ongoing clinical trials, phase 4 studies

\begin{tabular}{|c|c|c|c|}
\hline Study title & Conditions & Interventions & Locations \\
\hline $\begin{array}{l}\text { Evaluation of Ganovo (danoprevir) } \\
\text { combined with ritonavir in the treatment of } \\
\text { SARS-CoV-2 infection }\end{array}$ & COVID-19 & $\begin{array}{l}\text { Drug: Ganovo + ritonavir/interferon } \\
\text { nebulization }\end{array}$ & $\begin{array}{l}\text { - The Ninth Hospital of Nanchang, } \\
\text { Nanchang, Jiangxi, China }\end{array}$ \\
\hline $\begin{array}{l}\text { The use of tocilizumab in the management } \\
\text { of patients who have severe COVID-19 with } \\
\text { suspected pulmonary hyper inflammation }\end{array}$ & $\begin{array}{l}\text { COVID-19 } \\
\text { pneumonia }\end{array}$ & Drug: tocilizumab & $\begin{array}{l}\text { - Hadassah Medical Orginisation, } \\
\text { Jerusalem, Israel } \\
\text { - Barzilai Medical Center, Ashkelon, Israel } \\
\text { - Wolfson Medical Center, Holon, Israel } \\
\text { - Sheba Medical Center, Ramat Gan, Israel }\end{array}$ \\
\hline $\begin{array}{l}\text { Fluoxetine to reduce intubation and death } \\
\text { after COVID19 infection }\end{array}$ & $\begin{array}{l}\text { COVID-19 cytokine } \\
\text { storm }\end{array}$ & Drug: fluoxetine & University of Toledo, Toledo, OH, USA \\
\hline $\begin{array}{l}\text { Hydroxychloroquine and zinc with either } \\
\text { azithromycin or doxycycline for treatment } \\
\text { of COVID-19 in outpatient setting }\end{array}$ & COVID-19 & $\begin{array}{l}\text { Drug: hydroxychloroquine, } \\
\text { azithromycin, zinc sulfate, doxycycline }\end{array}$ & St Francis Hospital, Roslyn, NY, USA \\
\hline Favipiravir in hospitalized COVID-19 patients & COVID-19 & Drug: favipiravir, hydroxychloroquine & $\begin{array}{l}\text { Shahid Modarres Hospital, Shahid Behesht } \\
\text { University of Medical Sciences and Health } \\
\text { Services, Tehran, Iran }\end{array}$ \\
\hline $\begin{array}{l}\text { Azithromycin in hospitalized COVID-19 } \\
\text { patients }\end{array}$ & COVID-19 & $\begin{array}{l}\text { Drug: hydroxychloroquine, } \\
\text { azithromycin }\end{array}$ & $\begin{array}{l}\text { Shahid Modarres Hospital, Shahid Behesht } \\
\text { University of Medical Sciences and Health } \\
\text { Services, Tehran, Iran, Islamic Republic of }\end{array}$ \\
\hline $\begin{array}{l}\text { Prophylaxis of exposed COVID-19 individ- } \\
\text { uals with mild symptoms using chloroquine } \\
\text { compounds }\end{array}$ & $\begin{array}{l}\text { - SARS-CoV2 } \\
\text { - Symptomatic } \\
\text { condition } \\
\text { - COVID-19 }\end{array}$ & $\begin{array}{l}\text { - Drug: hydroxychloroquine sulfate } \\
\text { regular dose, hydroxychloroquine } \\
\text { sulfate loading dose, chloroquine, } \\
\text { placebo }\end{array}$ & $\begin{array}{l}\text { - Expo COVID Isolation Center/Mayo } \\
\text { Hospital Field Hospital, Lahore, Punjab, } \\
\text { Pakistan } \\
\text { - Mayo Hospital/King Edward Medical } \\
\text { University, Lahore, Punjab, Pakistan } \\
\text { - Pakistan Kidney and Liver Institute, } \\
\text { Lahore, Punjab, Pakistan }\end{array}$ \\
\hline $\begin{array}{l}\text { BCG vaccine for health care workers as } \\
\text { defense against COVID } 19\end{array}$ & $\begin{array}{l}\text { - Coronavirus } \\
\text { - Coronavirus } \\
\text { infection } \\
\text { - Coronavirus as } \\
\text { the cause of } \\
\text { diseases classified } \\
\text { elsewhere }\end{array}$ & $\begin{array}{l}\text { - Biological: BCG vaccine } \\
\text { - Biological: placebo vaccine }\end{array}$ & $\begin{array}{l}\text { - Cedars-Sinai Medical Center, Los Angeles } \\
\text { CA, USA } \\
\text { - Harvard T.H. Chan School of Public } \\
\text { Health, Boston, MA, USA } \\
\text { - Texas A\&M Family Care Clinic, Bryan, TX, } \\
\text { USA and } 4 \text { more }\end{array}$ \\
\hline $\begin{array}{l}\text { Hydroxychloroquine in patients with newly } \\
\text { diagnosed COVID-19 compared to standard } \\
\text { of care }\end{array}$ & $\begin{array}{l}\text { - COVID-19 } \\
\text { - Coronavirus } \\
\text { Infection } \\
\text { - SARS-CoV-2 } \\
\cdot \text { - } 2019-n \text { CoV } \\
\cdot 2019 \text { novel } \\
\text { coronavirus }\end{array}$ & $\begin{array}{l}\text { - Drug: hydroxychloroquine } \\
\text { - Dietary supplement: vitamin C }\end{array}$ & $\begin{array}{l}\text { Portland Providence Medical Center, } \\
\text { Portland, OR, USA }\end{array}$ \\
\hline $\begin{array}{l}\text { Efficacy of dexamethasone treatment for } \\
\text { patients with ARDS caused by COVID-19 }\end{array}$ & $\begin{array}{l}\text { Acute respiratory } \\
\text { distress syndrome } \\
\text { caused by COVID- } \\
19\end{array}$ & - Drug: dexamethasone & $\begin{array}{l}\text { - ICU, Hospital Universitari Mutua Terrassa, } \\
\text { Terrassa, Barcelona, Spain } \\
\text { - Hospital Universitario Dr. Negrin, Las } \\
\text { Palmas de Gran Canaria, Las Palmas, } \\
\text { Spain } \\
\text { - Department of Anesthesia, Hospital } \\
\text { Universitario de Cruces, Barakaldo, } \\
\text { Vizcaya, Spain and } 21 \text { more }\end{array}$ \\
\hline
\end{tabular}

\section{Conclusion}

COVID-19 has emerged as the most terrified and enormous viral infection. According to $\mathrm{WHO}$, the coronavirus might become an endemic disease. Originating from China as a global pandemic, it has influenced people on a large scale. There is no clear end that can be seen for this contagious disease. The only possible cure for this pandemic is prevention. We have to face it as a global community and support each other. The amplification of positivity will have a tremendous impact on the whole society. It is the duty of each individual for self-supervision and to report COVID-19 status, and challenging for those who appear to be ill. The other measure which can be followed to tackle this pandemic is healthy nourishment, sanitation, and hygiene practices robust connection and communication among children, and counseling to face the situation. Special care should be given to older people and pregnant ladies. It is better to get information only from the trusted sources; it is vital to get the facts and not the misinformation or 
rumors. Healthcare servants should have excellent and accurate communication with the public and must provide emotional and practical support. The ongoing pandemic of COVID-19 has caused not only notable morbidity and mortality in the world but also revealed significant systematic problems in the control and prevention of infectious diseases.

\section{Abbreviations}

ACE-2: Angiotensin-converting enzyme-2; ARDS: Acute respiratory distress syndrome; CoV: Coronavirus; COVID-19: Novel coronavirus infectious disease 2019; MERS-CoV: Middle East respiratory syndrome coronavirus; Nsps: nonstructural proteins; ORF: Open reading frame; RBD: Receptor-binding domain; RTC: Replicase-transcriptase complex; SARS-CoV: Severe acute respiratory syndrome coronavirus; WHO: World Health Organization

\section{Acknowledgements}

The authors express their sincere thanks to Ms. Fatma Rafiq Zakaria, Chairman of Maulana Azad Educational Trust Aurangabad Maharashtra, for her endless encouragement and support and for providing necessary facilities to carry out the above research work.

\section{Authors' contributions}

All authors participated in the work substantively and have approved the manuscript as submitted. The authors have no conflict of interest in the study. Drafting the article and critical revision of the article was carried out by SSS. Data collection for the formation of graphical abstract and various figures and tables was also contributed from her end. Conception or design of the work was carried out by SKS. He also contributed to the data collection for lifecycle, history, and origin. Data collection for pathogenesis and comparison of CoVs study was carried out by APJ. Data collection for diagnosis and treatment was carried out by MVKV. Data collection for clinical trials was carried out by DAN. Final approval of the version to be published was done by all the authors' SSS, APJ, DAN, MVKV, and SKS. All the authors have read and approved the manuscript. Each author has agreed with the publication of the manuscript.

\section{Funding}

No funding was received for this work

\section{Availability of data and materials}

The data and material are available upon request. The graphs and figures used in the manuscript were generated and analyzed and are not used anywhere else before.

\section{Ethics approval and consent to participate}

Not applicable

\section{Consent for publication}

Not applicable

\section{Competing interests}

I, on behalf of all the authors, hereby declare that there is no significant financial, professional, or personal competing interest that might have influenced the performance or presentation of the work described in this manuscript.

\section{Author details}

${ }^{1}$ Y. B. Chavan College of Pharmacy, Dr. Rafiq Zakaria Campus, Aurangabad 431001, India. ${ }^{2}$ Government College of Pharmacy, Aurangabad 431001, India.

Received: 24 June 2020 Accepted: 26 October 2020

Published online: 17 November 2020

\section{References}

1. Helena JM, Erica B, Paul B (2015) Coronaviruses: methods and protocols. Methods in Molecular Biology Springer, vol 1282. https://doi.org/10.1007/ 978-1-4939-2438-7
2. Hussin AR, Siddappa NB $(2020,109)$ The epidemiology and pathogenesis of coronavirus disease (COVID-19) outbreak. J Autoimmunity 102433 Elsevier. https://doi.org/10.1016/j.jaut.2020.102433

3. Mohsen R, Vida G, Zahra T (2020) Immune responses and pathogenesis of SARS-COV-2 during an outbreak in Iran: comparison with SARS and MERS. Rev Med Virol Wiley. https://doi.org/10.1002/rmv.2107

4. Tanu S (2020) A review of coronavirus disease-2019 (COVID-19). Indian J Pediatr 87(4):281-286. https://doi.org/10.1007/s12098-020-03263-6

5. Nanshan C, Zhou M, Dong $X$, Jieming Q, Gong F, Yang H, Yang Q, Wang J, Liu Y, Wei Y, Xia J'a, Yu T, Zhang X, Zhang L (2020) Epidemiological and clinical characteristics of 99 cases of 2019 novel coronavirus pneumonia in Wuhan, China: a descriptive study, vol 395, pp 507-513. DOI. https://doi.org/ 10.1016/S0140-6736(20)30211-7

6. Liangsheng Z, Fu-ming S, Fei C, Zhenguo L (2020) Origin and evolution of the 2019 novel coronavirus. Clinical Infectious Diseases, Infectious Disease society of America. https://doi.org/10.1093/cid/ciaa112

7. WHO Coronavirus Disease (COVID-19) Dashboard. https://covid19.who.int (Accessed on: 10 May 2020).

8. Jie C, Fang L, Zheng LS (2019) Origin and evolution of pathogenic coronaviruses. Nature Reviews. Microbiology 17. https://doi.org/10.1038/ s41579-018-0118-9

9. Sargeant C, Joan BD, Alwin MP, Orville TB (1949) A murine virus (JHM) causing disseminated encephalomyelitis with extensive destruction of myelin. I. Isolation and biological properties of the virus. In: Department of bacteriology and pathology Harvard medical school, pp 181-194

10. Rabaan AA, Al-Ahmed SH, Shafiul H, Ranjit S, Ruchi T, Yashpal SM, Kuldeep D, Yatoo MI, BA DK, Alfonso JR (2020) SARS-CoV-2, SARS-CoV, and MERSCoV: a comparative overview. Le Infezioni in Medicina. 2:174-184

11. Ceccarelli M, Berretta M, Venanzi ER, Nunnari G, Cacopardo B (2020) Editoria - Differences and similarities between severe acute respiratory syndrome (SARS)-coronavirus (CoV) and SARS-CoV-2. Would a rose by another name smell as sweet? Eur. Rev Med Pharmcol Sci. 24:2781-2783

12. Leung C (2020) The difference in the incubation period of 2019 novel coronavirus (SARS-CoV-2) infection between travelers to Hubei and nontravelers: the need for a longer quarantine period. Infect Control Hospital Epidemiol 41:594-596. https://doi.org/10.1017/ice.2020.81

13. Petrosillo N, Viceconte G, Ergonul O, Ippolito G, Petersen E (2020) COVID-19, SARS and MERS: are they closely related? Clin Microbiol Inf. https://doi.org/ 10.1016/j.cmi.2020.03.026

14. SARS-CoV-2 (Severe acute respiratory syndrome coronavirus 2) Sequences. https:// www.ncbi.nlm.nih.gov/genbank/sars-cov-2-seqs/ (Accessed on : 11 May 2020)

15. Daniel B. (2020). COVID-19 Radiopedia RID: 73913 DOI: https://radiopaedia. org/articles/covid-19-3?lang=gb.

16. Yong-Zhen Z, Edward CH (2020) A genomic perspective on the origin and emergence of SARS-CoV-2. Cell 181 Elsevier:223-227. https://doi.org/10. 1016/j.cell.2020.03.035

17. Sourav S, Kavita BA, Santosh K, Gupta RM (2020) Coronaviruses: origin and evolution. Med J Armed Forces India. https://doi.org/10.1016/j.mjafi. 2020.04.008

18. van der H L, Pyrc K, Jebbink MF, Vermeulen-Oost W, Berkhout RJM, Wolthers KC, Wertheim-van Dillen PME, Kaandorp J, Spaargaren J, Berkhout B (2004) dentification of a new human coronavirus. Nat Med 10(4). https://doi.org/ 10.1038/nm1024

19. Ye Z-W, Shuofeng Y, Kit-San Y, Sin-Yee F, Chi-Ping C, Dong-Yan J (2004) Identification of a new human coronavirus. Nat Med 10(4). https://doi.org/ 10.1038/nm1024

20. Hu D, Zhu C, Ai L, He T, Wang Y, Ye F, Lu Y, Ding C, Zhu X, Ruicheng LV, Zhu J, Hassan B, Feng Y, Tan W, Wang C (2018) Genomic characterization and infectivity of a novel SARS-like coronavirus in Chinese bats. Emerging Microbes Infections 7:154. https://doi.org/10.1038/s41426-018-0155-5

21. Saif ur Rehman, Laiba S, Awais I, Qingyou L (2020). Evolutionary trajectory for the emergence of novel coronavirus SARS-CoV-2. Pathogens. 9, 240. DOl: https://doi.org/10.3390/pathogens9030240.

22. Yudong Y, Richard GW (2018) MERS, SARS and other coronaviruses as causes of pneumonia, Asian Pacific Society of Respirology. Respirology. 23: 130-137. https://doi.org/10.1111/resp.13196

23. Ronald D, Maarten FJ, Sylvie MK, Martin D, Hulda RJ, Richard M, Margareta I, Herman G, Volker T, Lia VH (2013) Isolation and characterization of current human coronavirus strains in primary human epithelial cell cultures reveal differences in target cell tropism. Journal of Virology. Vol 87(11):6081-6090. https://doi.org/10.1128/JVl.03368-12 
24. World Health Organization. Novel coronavirus. Situation report - 4 (2019-nCoV). https://www.who.int/docs/defaultsource/9 (Accessed on: 24 Jan 2020)

25. Ben $H$, Xingyi G, Lin-Fa W, Zhengli S (2015) Bat origin of human coronaviruses. Virology Journal. 12:221. https://doi.org/10.1186/s12985-015-0422-1

26. Yan-Rong G, Qing-Dong Cao, Zhong-Si Hong, Yuan-Yang Tan, Shou-Deng Chen, Hong-Jun Jin, Kai-Sen Tan, De-Yun Wang, Yan Yan. (2020). The origin, transmission and clinical therapies on coronavirus disease 2019 (COVID-19) outbreak-an update on the status. Military Medical Research. 7:11. DOl: https://doi.org/10.1186/s40779-020-00240-0.

27. Anca Oana D, Aristidis T, Dana A, Oana C, Ovidiu Z, Marco V, Sterghios AM, Dimitris T, Marina G, Nikolaos D, Josef MD, Victor AT, Gennadii GO, Michael A, Demetrios AS, Daniela C (2020) A new threat from an old enemy: reemergence of coronavirus (Review). Int J Mol Med 45:1631-1643. https:// doi.org/10.3892/ijmm.2020.4555

28. Dharmendra K, Rishabha M, Pramod S (2020) Coronavirus: a review of COVID-19. Eurasian J Medicines Oncology 4(1):8-25. https://doi.org/10. 14744/ejmo.2020.51418

29. David AJT, Steven HM (1996) Coronavirus-medical microbiology, 4th edn. Samuel Baron University of Texas medical branch at Galveston, Galveston (TX)

30. Paul SM. (2006) The molecular biology of coronaviruses. Advances in virus research, Wadsworth Center, New York State Department of Health Albany. Vol 66. DOI: 10.1016/S0065-3527(06)66005-3.

31. Stuart S, Helmut W, Volker TM (1983). The biology of coronavirus institute of virology. Versbacher Strasse 7, 8700 Wurzburg, federal republic of Germany Journal general, virology. 64, 761-776. DOl: 0022-1317/83/0000-5501.

32. Susan RW, Sonia NM (2005) Coronavirus pathogenesis and the emerging pathogen severe acute respiratory syndrome coronavirus. Microbiol. Mol Biol Rev. Vol. 69:635-664. https://doi.org/10.1128/MMBR.69.4.635-664

33. Luis E (2005) Coronavirus replication and reverse genetics. Springer. 287:1-30

34. Kathrin VH (2004) Coronaviruses (Coronaviridae). Encyclopedia of Virology Elsevier.:291-298. https://doi.org/10.1006/rwvi.1999.0055

35. Allison LT, Ralph SB. (2012). Baric SARS coronavirus pathogenesis: host innate immune responses and viral antagonism of interferon. Curr opin in virol, Elsevier. 2:264-275. DOl: https://doi.org/10.1016/j.coviro.2012.04.004.

36. Hanuman SD; Saurabh SD. (2020). Genome organization of Covid-19 and emerging severe acute respiratory syndrome Covid-19 outbreak: a pandemic. Eurasian J. med onco. 4(2), 107-115. DOI: 10.14744/ejmo.2020.96781.

37. Kristian GA, Andrew R, lan WL, Edward CH, Robert FG (2020) The proximal origin of SARS-CoV-2. Nat Med. 26:450-455. https://doi.org/10.1038/s41591020-0820-9

38. Oscar AM, Richard JO, Joshua BS, David LR (2020). No evidence for distinct types in the evolution of SARS-CoV-2. Virus evolution. 6(1): veaa034. DOI: 10. 1093/ve/veaa034.

39. Xiaolu T. et al. (2020). On the origin and continuing evolution of SARS-CoV2, Nat Sci Rev. 0: 1-12, DOl: https://doi.org/10.1093/nsr/nwaa036.

40. Anthony RF, Stanley Perlman. (2015). Coronaviruses: an overview of their replication and pathogenesis Helena Jane Maier et al. (eds.). Coronaviruses: methods and protocols, Methods in Mol. Biol. Springer. Vol 1282. DOI: 10. 1007/978-1-4939-2438-7.

41. Koichi Y, Miho F, Sophia K (2020) COVID-19 pathophysiology: a review. J. Clin. Immunol. Elsevier. 215. https://doi.org/10.1016/j.clim.2020.108427

42. Guan W, Ni YH, Liang W, Ou C, He J, Liu L, Shan H, Lei C, Hui DSC, Du B, Li L, Zeng G, Yuen K-Y, Chen R, Tang C, Wang T, Chen P, Xiang J, Li S, Wang JI, Liang Z, Peng Y, Wei L, Liu Y, Hu Y-h, Peng P, Wang J-m, Liu J, Chen Z, Li G, Zheng Z, Qiu S, Luo J, Ye C, Zhu S, Zhong N (2020) Clinical characteristics of coronavirus disease 2019 in China. N Engl J. Med. 382:1708-1720. https:// doi.org/10.1056/NEJMoa2002032

43. Robert JM (2020) Pathogenesis of COVID-19 from a cell biology perspective. Eur Resp J. 55:2000607. https://doi.org/10.1183/13993003.00607-2020

44. Jantien AB; Don K, Jacco W. (2020). Incubation period of 2019 novel coronavirus (2019- nCoV) infections among travellers from Wuhan, China, 20-28 January 2020. Vol 25(5). DOl: https://doi.org/10.2807/1560-7917.ES. 2020.25.5.2000062

45. Victor V, Fang VJ, Wu JT, Lai-Ming H, Peiris JSM, Leung GM, Cowling BJ (2015) Incubation period duration and severity of clinical disease following severe acute respiratory syndrome coronavirus infection. Epidemiology 26(5):666-669. https://doi.org/10.1097/EDE.0000000000000339

46. Stephen AL. (2020). The incubation period of coronavirus disease 2019 (COVID-19) From Publicly Reported Confirmed Cases: Estimation and
Application. Annals of internal medicine. https://www.acpjournals.org/doi/1 0.7326/M20-0504,. DOl: https://doi.org/10.7326/M20-0504.

47. David JC, Scott JB, Keith MO, Mary LW, Michael SB, Molly MM, (2020). What is the incubation period for coronavirus disease 2019 (COVID-19)? Drg. Dis Medsp. https://www.medscape.com/answers/2500114-197431/what-is-theincubation-period-for-coronavirus-disease-2019-covid-19.

48. Lauer SA, Grantz KH, Bi Q. Estimated incubation period of COVID-19. American college of cardiology. https://www.acc.org/latest-in-cardiology/ journal-scans/2020/05/11/15/18/the-incubation-period-of-coronavirusdisease [Accessed on: 29 May 2020].

49. Coronavirus incubation could be as long as 27 days, Chinese provincial government says https://www.reuters.com/article/us-china-healthincubation/coronavirus-incubation-could-be-as-long-as-27-days-chineseprovincial-government-says-idUSKCN20G06W [date of acess: 29 may 2020]

50. New study on COVID-19 estimates 5.1 days for incubation period. Science news. https://www.sciencedaily.com/releases/2020/03/200310164744.htm [Accessed on 29 may 2020].

51. Stephen GB COVID-19 Incubation period: an update NEJM journal watch. https://www.jwatch.org/na51083/2020/03/13/covid-19-incubation-periodupdate. [Accessed on 29 may 2020].

52. Xu Z, Lei $S$, Yijin W, Jiyuan $Z$, Lei $H$, Chao Z, Shuhong L, Peng Z, Hongxia L, Li Z, Yanhong T, Changqing B, Tingting G, Jinwen S, Peng $X$, Jinghui D, Jingmin Z, Fu-Sheng W (2020) Pathological findings of COVID-19 associated with acute respiratory distress syndrome. Lancet Respir Med 8:420-422. https://doi.org/10.1016/\$2213-2600(20)30076-X

53. Linlin B, Wei D, Huang B, Gao H, Liu J, Lili R, Wei Q, Pin Y, Yanfeng X, Qi F, Yajin Q, Li F, Qi L, Wenling W, Jing X, Shuran G, Mingya L, Guanpeng W, Shunyi W, Zhiqi S, Linna Z, Peipei L, Li Z, Fei Y, Huijuan W, Weimin Z, Na Z, Wei Z, Haisheng Y, Xiaojuan Z, Li G, Lan C, Conghui W, Ying W, Xinming W, Yan X, Qiangming S, Hongqi L, Fanli Z, Chunxia M, Lingmei $Y$, Mengli $Y$, Jun H, Wenbo X, Wenjie T, Xiaozhong P, Qi J, Guizhen W, Qin C (2020) The pathogenicity of SARS-CoV-2 in hACE2 transgenic mice. Nature. https://doi. org/10.1038/s41586-020-2312-y

54. Yanan C, Li L, Zhimin F, Shengqing W, Peide H, Xiaohui S, Fang W, Xuanlin $\mathrm{H}$, Guang N, Weiqing W (2020) Comparative genetic analysis of the novel coronavirus (2019-nCoV/SARS-CoV-2) receptor ACE2 in different populations. Cell Discovery. 6(11). https://doi.org/10.1038/s41421-020-0147-1

55. Yuefei J. Haiyan Y, Wangquan J, Weidong W, Shuaiyin C, Weiguo Z, Guangcai D (2020) Virology, epidemiology, pathogenesis, and control of COVID-19. Viruses. 12, 372; DOl: https://doi.org/10.3390/v12040372.

56. Marco C, Michael R, Arturo C, Scott CD, Raffaela DN (2020) Features, evaluation and treatment and coronavirus (COVID-19). Stat pearls, DOI https://www.ncbi.n/m.nih.gov/books/NBK554776/

57. Li F (2016) Structure, function, and evolution of coronavirus spike proteins Annu Rev Virol 29; 3(1):237-261. https://doi.org/10.1146/annurev-virology110615-042301

58. Matthew ZT, Chek MP, Laurent R, Paul AM, Lisa FP (2020) The trinity of COVID-19: immunity, inflammation and intervention. Nat Rev Immunol. https://doi.org/10.1038/s41577-020-0311-8

59. Leila M, Sorayya G (2020) Genotype and phenotype of COVID-19: their roles in pathogenesis. J. Microbiol Immu Inf. https://doi.org/10.1016/j. jmii.2020.03.022

60. Luca S, Luca S Jr, Robert Z, Alexei V (2020) Neuro-infection, may contribute to pathophysiology and clinical manifestations of COVID-19. Acta Physiologica. 00:e13473. https://doi.org/10.1111/apha.13473

61. Ying- Ying Z, Yi- Tong M, Jin- Ying Z, Xiang X (2020) COVID-19 and the cardiovascular system. Nature Reviews Cardiology. 17. https://doi.org/10. 1038/s41569-020-0360-5

62. Rahila S. Deepshikha S, Shweta B, Dinesh G (2020). Comparative analyses of SAR-CoV2 genomes from different geographical locations and other coronavirus family genomes reveals unique features potentially consequential to host-virus interaction and pathogenesis, BioRxiv preprint DOl: https://doi.org/10.1101/2020.03.21.001586.

63. Coronavirus disease 2019, symptoms. Centres for disease control and prevention. https://www.cdc.gov/coronavirus/2019-ncov/symptoms-testing/ symptoms.html [Accessed on: 29 May 2020].

64. Coronavirus (COVID-19). National institutes of Health. https://www.nih.gov/ health-information/coronavirus [Accessed on: 14 May 2020].

65. Q \& A on coronaviruses (COVID-19) World Health Organization. https:// www.who.int/emergencies/diseases/novel-coronavirus-2019/question-andanswers-hub/q-a-detail/q-a-coronaviruses [Accessed on: 30 May 2020] 
66. How long does the coronavirus live on different surfaces? Health line. https://www.healthline.com/health/how-long-does-coronavirus-last-onsurfaces [Accessed on: 30 May 2020].

67. Coronavirus disease 2019, testing for COVID-19. Centers for disease control and prevention. https://www.cdc.gov/coronavirus/2019-ncov/symptomstesting/testing.html [Accessed on: 30 May 2020]

68. Coronavirus disease 2019, Test for current infection. Centers for disease control and prevention. https://www.cdc.gov/coronavirus/2019-ncov/ testing/diagnostic-testing.html [Accessed on: 31 May 2020]

69. Coronavirus disease 2019, Test for past infection. Centers for disease control and prevention. https://www.cdc.gov/coronavirus/2019-ncov/testing/ serology-overview.html [31 May 2020].

70. Yehuda S (2020) Corona (COVID-19) time musings: our involvement in COVID-19 pathogenesis, diagnosis, treatment and vaccine planning. Autoimmun Rev. Elsevier. https://doi.org/10.1016/j.autrev.2020.102538

71. Yixuan W, Wang Y, Chen Y, Qingsong Q (2020) Unique epidemiological and clinical features of the emerging 2019 novel coronavirus pneumonia (COVID-19) implicate special control measures. J. Med Virol Wiley 92:568576. https://doi.org/10.1002/jmv.25748

72. Stacey K. Adel M, Stanley L, Alison M, Laura S, Katherine O, (2004). Learning from SARS: preparing for the next disease outbreak, workshop summary. DOl: https://www.nap.edu/read/10915/chapter/1.

73. Adeel HS, Fahad NS, Somia J, Jude KE, Ali A (2020) Coronavirus (COVID-19): a review of clinical features, diagnosis, and treatment. Cureus. 12(3):e7355. https://doi.org/10.7759/cureus.7355

74. Zhong Z, Hu Y, Yu Q, Yuxin L, Peng L, Huang W, Liu J, Liu J, Xie X, Zhao W (2020) Multistage CT features of coronavirus disease 2019. J. Cent South Univ. (Medical Science) 45(3). https://doi.org/10.11817/j.issn.1672-7347.2020.200144

75. Chun-Rong Q-YL, Jian-Heng Z, Tao Q, Zhi Tao C, Wen-Yang J, Jing Z, Qin C, Gang C, Li N, Chun-Yan W, He J-X (2020) Recommended prophylactic and management strategies for severe acute respiratory syndrome coronavirus 2 infection in transplant recipients. Chronic Diseases and Translational Med. https://doi.org/10.1016/j.cdtm.2020.02.003

76. Coronavirus disease 2019, Clinical care guidance. Centers for disease control and prevention https://www.cdc.gov/coronavirus/2019-ncov/hcp/clinicalguidance-management-patients.html [Accessed on 31 May 2020].

77. Li T (2020) Diagnosis and clinical management of severe acute respiratory syndrome coronavirus 2 (SARSCoV-2) infection: an operational recommendation of Peking Union Medical College Hospital (V2.0). Emerg Micrb Inf Taylor and Francis 9. https://doi.org/10.1080/22221751.2020.1735265

78. Kunling S, Yonghong Y, Tianyou W, Dongchi Z, Yi J, Runming J, Yueje Z, Baoping X, Zhengde X, Likai L, Yunxiao S, Xiaoxia L, Sainan S, Yan B, Jikui D, Min L, Leping Y, Xuefeng W, Yongyan W, Liwei G (2020) Diagnosis, treatment, and prevention of 2019 novel coronavirus infection in children: experts' consensus statement. World J. Pediatr. https://doi. org/10.1007/s12519-020-00343-7

79. Israel Junior BN, Nensi C, Hebatullah MA, Thilo CG, Umesh J, Ishanka W, Meisam AE, Vinicius TC, Ana M, Ana J, Nelson CJ, Tina PP, Irena ZG, Silvana MMG, Nicola LB, Maria B, Ahmad S, Mohammad A, Maoyi T, Diana MCA, Donal PM, Milena SM (2020) Novel coronavirus infection (COVID-19) in humans: a scoping review and meta-analysis. J. Clin. Med. 9:941. https://doi. org/10.3390/jcm9040941

80. https://covid19treatmentguidelines.nih.gov/whats-new/[Accessed on: 31 May 2020]

81. Phulen S, Manisha P, Pramod A, Hardeep K, Subodh K, Bikash M (2020) Therapeutic options for the treatment of 2019-novel coronavirus: an evidencebased approach. Ind J Pharmacol 52(1). https://doi.org/10.4103/ijp.IJP_119_20

82. Els K, Sandra L, Leen V, Evelien R, Jannick V, Marc Van R, Piet M (2009) Antiviral Activity of chloroquine against human coronavirus OC43 infection in newborn mice. Antmicrob. Agents Chemother 53(8):3416-3421. https:// doi.org/10.1128/AAC.01509-08

83. Lopinavir/Ritonavir, Ribavirin and IFN-beta combination for nCOV treatment. https://clinicaltrials.gov/ct2/show/NCT04276688?term=lopinavir\&cond= Corona+Virus+Infection\&draw=2\&rank=2 [Accessed on: 25 May 2020].

84. Harapan H, Naoya I, Amanda Y, Wira W, Synat K, Haypheng T, Dewi M, Zinatul H, Abram LW, Mudatsir M (2020) Coronavirus disease 2019 (COVID19): a literature review. J. Inf Pub Health. 13:667-673. https://doi.org/10. 1016/j.jiph.2020.03.019

85. Zhenwei Y, Jialong L, Yunjiao Z, Xixian Z, Qiu Z, Liu J (2020) The effect of corticosteroid treatment on patients with coronavirus infection: a systematic review and meta-analysis. J. Inf, Elsevier 20:59. https://doi.org/10.1016/j.jinf. 2020.03.062
86. Nicola V, Jacopo D, Lin Y, Roberto T, Barbagallo M, Pierluigi L, Erik L, Stefano C, Damiano P, Liye Z, Mark AT, Petre Cl, Mike T, Lopez-Sanchez GF, Lee S (2020) Use of corticosteroids in coronavirus disease 2019 pneumonia: a systematic review of the literature. Frontiers Med 7(170). https://doi.org/10. 3389/fmed.2020.00170

87. World Health Organization. Clinical management of severe acute respiratory infection when novel coronavirus (nCoV) infection is suspected: Interim guidance. https://www.who.int/docs/default-source/coronaviruse/clinicalmanagement-of-novel-cov.pdf?sfvrsn=bc7da517_2\&download=true. [Accessed on: 25 May 2020]

88. Rand A, Tawheeda B, Ibrahim H, Shahd HS, Shiema A, Kinda S, Joanne ND, Mohamed YK, Mohamed A, Abukhattab M, Alsoub HA, Muna AA, Ali SO (2020) Tocilizumab for the treatment of severe coronavirus disease 2019. J Med Virol, Wiley:1-8. https://doi.org/10.1002/jmv.25964

89. Binqing F, Xiaoling $X$, Haiming W (2020) Why tocilizumab could be an effective treatment for severe COVID-19? J. Trans Med 18:164. https://doi. org/10.1186/s12967-020-02339-3

90. Leon C, Julian DD, Mike GC, David AJ, Kylie MW (2020) The FDA-approved drug ivermectin inhibits the replication of SARS-CoV-2 in vitro. Antivi Res 178. https://doi.org/10.1016/j.antiviral.2020.104787

91. Richard ON, Edward B, Ivan K, Paul OB (2020) A comparison analysis on remdesivir, favipiravir, hydroxychloroquine, chloroquine and azithromycin in the treatment of corona virus disease 2019. World J Pharm Pceut Sci (covid19) - a rev. 9(5):121-133. https://doi.org/10.20959/wjpps20205-16143

92. https://www.ashp.org/ [Accessed on: 25 May 2020]

93. Rahmet G, Imran H, Firdevs A (2020) COVID-19: prevention and control measures in community. Turk J Med Sci 50:571-577. https://doi.org/10.3906/ sag-2004-146

94. Jiao Z, Shoucai W, Lingzhong X (2020) Asymptomatic carriers of COVID-19 as a concern for disease prevention and control: more testing, more followup. BioSci Trend Adv Pub. https://doi.org/10.5582/bst.2020.03069

95. World health organization. Infection prevention and control during health care when novel coronavirus ( $\mathrm{nCoV}$ ) infection is suspected Interim guidance 25 January 2020. https://apps.who.int/iris/rest/bitstreams/1266296/retrieve [Accessed on 25 May 2020]

96. Alexandra P (2020) The economics of infection prevention: why it is crucial to invest in hand hygiene and nurses during the novel coronavirus pandemic. J. Inf 19:4. https://doi.org/10.1016/j.jinf.2020.04.029

97. Farfour E, Ballester MC, Lecuru M, Verrat A, Imhaus E, Mellot F, Karnycheff F, Vasse M, Cerf C, Lesprit P (2020) COVID-19: before stopping specific infection control measures, be sure to exclude the diagnosis. J. Hosp Inf. DOl. https://doi.org/10.1016/j.jhin.2020.04.021

98. Tony K. (2020). Australian Government releases face masks to protect against coronavirus, thelancet.com/respiratory Vol 8. DOl: https://doi.org/10. 1016/S2213-2600(20)30064-3.

99. Sasmita P, Meng S, Wu Y-J, Mao Y-P, Ye R-X, Qing-Zhi W, Chang S, Sean S, Scott R, Hein R, Huan Z (2020) Epidemiology, causes, clinical manifestation and diagnosis, prevention and control of coronavirus disease (COVID-19) during the early outbreak period: a scoping review. Infect Dis Pov 9:29. https://doi.org/10.1186/s40249-020-00646

100. Maria N. Niamh ON, Catrin S, Mehdi K, Maliha A, Riaz A (2020). Evidence based management guideline for the COVID-19 pandemic - review article. Int J. Surg. 77. 206-216, DOI: https://doi.org/10.1016/j.ijsu.2020.04.001.

101. Mohsen B, Jeffery D, Navin J, Sharon EJ (2020) Art of prevention: life in the time of coronavirus. Int J Women Dermat. https://doi.org/10.1016/j.ijwd. 2020.03.046

102. Kamleshur R, Stephanie GM (2020) Coronavirus disease: a review of a new threat to public health. Cureus 12(3):e7276. https://doi.org/10.7759/cureus.7276

103. Sandip M, Tarun B, Nimalan A, Anup A, Amartya C, Manoj M, Raman RG, Swarup S (2020) Prudent public health intervention strategies to control the coronavirus disease 2019 transmission in India: a mathematical modelbased approach. Indian J Med Res 151:190-199. https://doi.org/10.4103/ijmr. IJMR_504_20

104. Zebin Z, Xin L, Feng L, Gaofeng Z, Chunfeng M, Liangxu W (2020) Prediction of the COVID-19 spread in African countries and implications for prevention and controls. Sci Total Environment. https://doi.org/10.1016/j. scitotenv.2020.138959

105. Ya-Ting C, Chun-Yu L, Ming-Ju T, Ching-Tzu H, Chia-Wen H, Po-Liang L, Ming-Feng H (2020) Infection control measures of a Taiwanese hospital to confront the COVID-19 pandemic. J Med Sci 36:296-304. https://doi.org/10. 1002/kjm2.12228 
106. Huang $Y$, Qingqing $W$, Ping $W$, Yan $X$, Lei $W$, Yusui Z, Dingming Y, Yue $X$, LV Q, Shuiyang X (2020) Measures undertaken in China to avoid COVID-19 infection: internet-based, cross-sectional survey study. J. Med Inter Res. 22(5):e18718. https://doi.org/10.2196/18718

107. Qiangsheng H, Yu K (2020) An evaluation model of COVID-19 spread control and prevention: effectiveness analysis based on immigration population data in China. JMIR Public Health and Surveillance on. https:// doi.org/10.2196/preprints. 18638

108. Clinical trials. Gov. United States national library of medicine. https:// clinicaltrials.gov/ct2/results? cond=COVID19\&term $=\&$ cntry $=\&$ state $=\&$ city $=$ \&dist=\&flds=aby [Accessed on 24 May 2020]

109. Catrin S, Zaid A, Niamh ON, Mehdi K, Ahmed K, Al-Jabir A, Christos I, Riaz A (2020) World Health Organization declares global emergency: a review of the 2019 novel coronavirus (COVID-19). Inter J. Surg 76:71-76. https://doi. org/10.1016/j.jiju.2020.02.034

110. Long term impact of COVID-19 pandemic on healthcare scenarios in India. Express Pharma. https://www.expresspharma.in/amp/guest-blogs/long-termimpact-of-covid-19-pandemic-on-healthcare-scenario-in-india/ [Accessed on 14 May 2020]

111. Henrietta HF. (2020). A wakeup call: COVID 19 and its impact on children's health and wellbeing The Lancet global health, Elsevier DOI: https://doi.org/ 10.1016/S2214-109X(20)30238-2 Link: https://www.thelancet.com/journals/ langlo/article/PIIS2214-109X(20)30238-2/fulltext

112. http://www.euro.who.int/en/health-topics/health-emergencies/pages/whoswork-in-emergencies. [Accessed on May 15 2020]

113. Prakah NT (2020) COVID-19: impact on health of people \& wealth of nations. Indian Journal Med Res. 151:121-123. https://doi.org/10.4103/ijmr.IJMR_664_20

114. https:/www.ncbinlm.nih.gov/pubmed/32202260 [Accessed on 15 May 2020]

115. Ana S. (2020). How COVID-19 affects women's sexual and reproduction health. Medical News Today. https:/www.medicalnewstoday.com/articles/how-covid-1 9-affects-womens-sexual-and-reproductive-health [Accessed on May 15 2020]

116. Lisheng W, Yiru W, Dawei Y, Qingquan L (2020). Review of the 2019 novel coronavirus (SARS-CoV-2) based on current evidence, Inter J. Antimic Agts. 12:43, DOI: https://doi.org/10.1016/j.ijantimicag.2020.105

117. How to learn to live with COVID-19. The Times of India. https://timesofindia. indiatimes.com/india/have-to-learn-to-live-with-covid-19-govt/articleshow/ 75638429.cms [Accessed on 15 May 2020]

118. Kit SY, Zi -Wei Y, Sin-Yee F, Chi-Ping C, Dong-Yan J (2020) SARS-CoV-2 and COVID-19: the most important research questions. Cell Bioscience 10:40. https://doi.org/10.1186/s13578-020-00404-4

119. Get ready to live with COVID-19. Forbes. https://www.forbes.com/sites/ toddhixon/2020/03/12/get-ready-to-live-with-covid-19/\#36c2d8c14782 [Accessed on: 20 May 2020].

120. The Lancet Infectious Disease. (2020). Challenges of coronavirus disease The Lancet Infectious Diseases. 2019. Vol 20(3), P261. DOI: https://doi.org/10. 1016/S1473-3099(20)30072-4.

121. Stanley P (2020) Another decade, another coronavirus. N Eng J. Med. 382:8. https://doi.org/10.1056/NEJMe1917479

122. Anil KG; Divya R.S.B.B.R (2020). Charting the challenges behind the testing of COVID-19 in developing countries: Nepal as a case study Biosafety and Health. DOl: https://doi.org/10.1016/j.bsheal.2020.05.002.

123. Balachanda V, Kaavya J, Mahalaxmi I, Arul N, Vivekanandhan G, Bupesh G, Singaravelu G, Anila V, Dhivya V, Harsha G, Kamarajan R, Pattanathu K.S.M.R, Ssang-Goo Cho, Nachimuthu SK, Mohana DS. (2020). COVID-19: a promising cure for the global panic, Sci Total Env. 725 138277. DOI: https://doi.org/10. 1016/j.scitotenv.2020.138277.

124. Muhammad AS, Suliman K, Abeer K, Nadia B, Rabeea S (2020) COVID-19 infection: origin, transmission, and characteristics of human coronaviruses. J. Adv Res. 24:91-98. https://doi.org/10.1016/j.jare.2020.03.005

125. Emily H (2020) COVID-19 testing: challenges, limitations and suggestions for improvement. Med Pharmacol. https://doi.org/10.20944/preprints202004.0155.v1

126. Wang-Huei S, Wen-Chien K, Yhu-Chering H, Po-Ren H (2020) SARS-CoV-2 and COVID-19. J. Microbiol Immunol Infect. https://doi.org/10.1016/j.jmii.2020.03.033

127. Pascalina CK, Nathan K, Alimuddin Z (2020). COVID-19 and malaria: a symptom screening challenge for malaria endemic countries, Int J. Infect Dis. 94 151-153, Elsevier. DOl: https://doi.org/10.1016/j.ijid.2020.04.007.

\section{Publisher's Note}

Springer Nature remains neutral with regard to jurisdictional claims in published maps and institutional affiliations.

\section{Submit your manuscript to a SpringerOpen ${ }^{\circ}$ journal and benefit from:}

- Convenient online submission

- Rigorous peer review

- Open access: articles freely available online

High visibility within the field

- Retaining the copyright to your article

Submit your next manuscript at $\boldsymbol{\nabla}$ springeropen.com 